\title{
Pintores españoles y portadas de discos
}

\author{
Francisco PÉrez-Bryan Muñoz*
}

Spanish painters and album covers

\begin{abstract}
RESUMEN
Con la invención del fonógrafo en el siglo $X I X$ y el desarrollo de las compañías discográficas a mediados del XX la música ha jugado un papel fundamental en la sociedad de nuestro tiempo. Desde los primeros carteles del "Art Nouveau» la imagen ha acompañado, a través de las artes gráficas, a la industria de la cultura y el entretenimiento, siendo un reclamo para su consumo. Las portadas de discos son el resultado de la convergencia de varias sensibilidades estéticas, en este trabajo nos centraremos en dos de ellas: la pintura y la música. Son muchos los pintores que han unido su talento a los músicos y viceversa, de las vanguardias históricas a la nueva figuración, de la canción protesta al pop.
\end{abstract}

PALABRAS CLAVE:

Música, discos, pintura, portadas, carátulas, "Nova canço», cantautores, poprock, vanguardias, “Dau al Set», «El paso», «Popart»...

\begin{abstract}
With the invention of the phonograph in the nineteenth century and the development of the record companies to mid-twentieth century, music has played a fundamental role in society of our time. From the first signs of "Art Nouveau", the image is accompanied by graphic arts industry culture and entertainment being the claim for consumption. The album covers are the result of the convergence of several aesthetic sensibilities. In this paper we focus two of them: painting and music. The are many painter who have combined their talents to the musicians and viceversa. From historical avant-garde to figurative art, from protest song pop.
\end{abstract}

KEY WORDS:

Music, albums, painting, covers, «Nova canço», singers, poprock, "Dau sal set», «El Paso», Pop art.

\section{INTRODUCCIÓN}

Cuando Edison inventó el fonógrafo en 1887 estaba poniendo la primera piedra del gran edificio de la comunicación de nuestro tiempo a través de la reproducción del sonido. Unos años después el gramófono utilizando un disco plano encontraba el soporte adecuado para su reproducción, pero faltaba un motor que lo hiciera girar a velocidad constante y un amplificador para que tuviéramos «el tocadiscos» 1 .

* ppbryan@atlantida.es

1 El tocadiscos apareció por primera vez en 1925 al mismo tiempo que los amplificadores de válvulas. Al aplicarle un motor eléctrico hacía que el plato giradiscos rotara a una velocidad de 16rpm, 45rpm, 33rpm1/3 o 78rpm. 
Con él y los discos de vinilo ${ }^{2}$, la música se convierte en objeto de consumo de masas impulsada por la industria discográfica y otros medios como la radio llegando hasta el último rincón del planeta. Son los discos a $33 \mathrm{rpm} 1 / 3$ conocidos como $\mathrm{Lps}^{3}$ y los de $45 \mathrm{rpm}^{4}$ los que inundan el mercado multiplicándose por millones ${ }^{5}$.

Ahora en el siglo XXI y con la aparición de las nuevas tecnologías ese soporte, y los que vinieron después, como el CD, son objetos de coleccionistas mientras que la industria que los creó está agonizando. Pero en estos años de historia, la música nos dejó interesantes encuentros con artistas plásticos. Veamos los más significativos dentro de la música española.

\section{¿Quiénes fueron los primeros?}

Si la Bienal Hispanoamericana de 1951 consagra el Arte Contemporáneo es también a partir de ese año cuando se empiezan a comercializar los discos a 45rpm. Son los propios diseñadores a sueldo de las discográficas los que realizan estos primeros trabajos. No obstante, será a partir de los años 60 cuando adquiere gran importancia el contenido musical y la imagen que se proyecta en la portada, en función siempre de criterios comerciales, políticos o sociales. Y son los cantautores — siguiendo una vieja tradición juglaresca castellana para cantar a la realidad socio cultural que les rodea e influidos por poetas compositores-intérpretes como Brassens, Brel o Dylan- los que comienzan esa fructífera colaboración con pintores consagrados mundialmente, quienes además se identifican con estos jóvenes y su música.

\section{LAS VANGUARDIAS HISTÓRICAS: PICASSO, MIRÓ, DALÍ}

Fue Paco Ibáñez con su primer disco de 1964, un homenaje a la poesía de Lorca y Góngora, quien abre la senda para la unión entre la pintura y la música en las portadas de discos.

"A principios de la década de los 50, cuando me instale con la familia en París, yo no era lector de poesía. Un amigo chileno me descubrió el canto general de $\mathrm{Ne}$ ruda, por ahí empecé, luego alguien me regalo un libro de poemas de Góngora, un poeta difícil, incluso el popular. Y por casualidad le puse música a la más bella niña»6

\footnotetext{
${ }^{2}$ Los discos de vinilo están formados por un material plástico y sólido que se fabrica mediante la polimerización del cloruro de vinilo. La expansión se produjo durante la Segunda Guerra Mundial, utilizada para informar a las tropas del frente de los sucesos en los Estados Unidos.

${ }^{3}$ Long Play o disco de larga duración 12 pulgadas $(30 \mathrm{~cm})$ y con capacidad para 45 minutos.

4 Disco conocido como sencillo de 7 pulgadas y capacidad de 5 minutos y una canción por cara.

5 Cfr. H.E. Roys, Disk Recording and reproduction, Dourden, Hutchison and Ross, 1978.

${ }^{6}$ Declaraciones a el periódico El País, 21 de diciembre de 2008.
} 
Aquel París fue el que llevó a Paco hasta el Hotel Meurice donde Dalí montaba sus famosos happenings.

«Mi hermano era amigo de Dalí y del Capitán Moore. Aquello era insólito, se paseaba un tipo con una pantera encadenada, a mí me empujaron para que saliera en la foto. De ese encuentro salió mi amistad con Dalí, que pronto escuchó las canciones de Lorca y Góngora que quería publicar en mi primer disco. Especialmente quedó impresionado por "La Canción del Jinete». Dalí ilustró la canción con una gran mancha de tinta negra, sangre a la manera española».

Dalí dijo lo siguiente sobre el poema que originó la portada de este disco:

"Me ha cabido a mi el gran honor de esbozar una imagen de esta "Canción del Jinete" y puede decirse que lo he hecho con una sola mancha de tinta, una especie de salpicadura...Por lo demás, Federico García Lorca fue el primero que dijo en una de sus poesías que todo lo que Dios puede desplegar, en cuanto a magnificencia y sublimidad, es siempre, así mismo como una especie de salpicadura, como manchones imprevistos" ${ }^{7}$

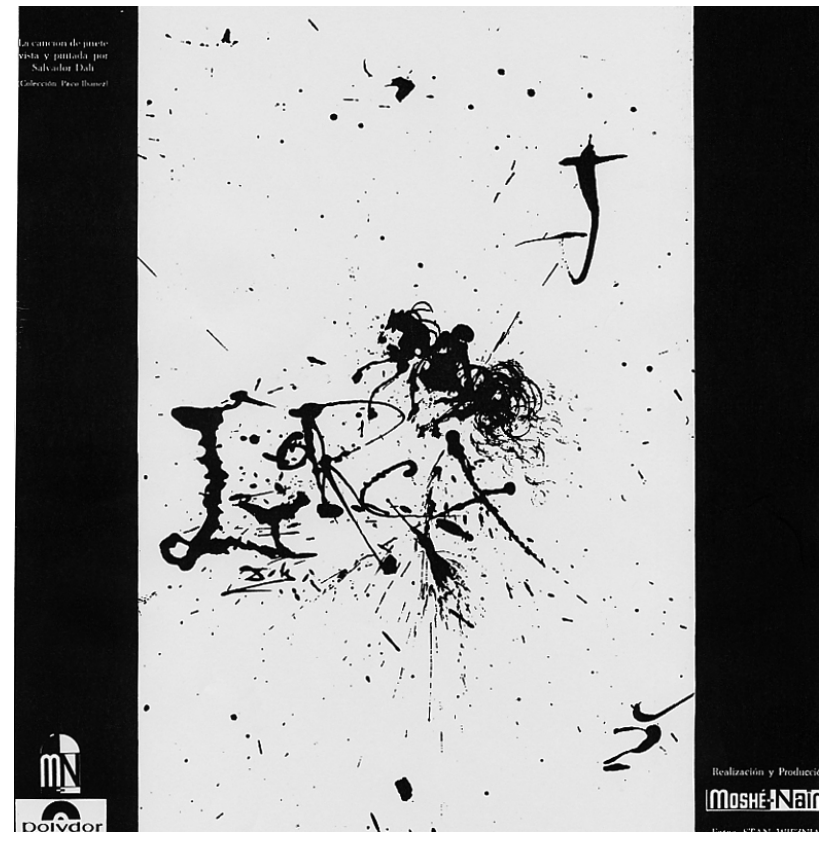

No se puede entender la relación de la música y la pintura sin «La nova canço ${ }^{8}$, movimiento inspirado por escritores como Josep Bentet, Joan Brossa o Maurici Serrahima, que da origen a las primeras canciones que responden a un clima de reivindicación de la cultura catalana y especialmente de su lengua; sur-

7 Paco lbáñez, La canción del jinete, Polidor, 1964, contraportada.

8 AA.VV, La nova canço. La veu d'un poble, Generalitat de Catalunya, 2010. 
gen primero en los ambientes universitarios para posteriormente extenderse a los diferentes contextos de la sociedad catalana. Raimón es uno de sus máximos exponentes. Nacido en Jativa, se trasladó a Valencia para estudiar historia. Sus gustos musicales iban de Juliet Grecó a los Platters, pasando por Juanito Valderrama. Pero no es hasta que descubre a poetas como Salvador Espriu, Josep Pla o Joan Fuster cuando se convierte en portavoz de la canción en catalán.

En junio de 1966 Miró asistió al primer concierto de Raimón en el Olympia de París. Poco tiempo después sale el disco «La Roda del Temps», musicación íntegra de la sección central del libro de Salvador Espriu El caminant i el mur, doce poemas que trazan el ciclo solar y a la vez el ciclo vital del hombre. Miró hace por primera vez en su vida un trabajo para la portada de un disco y en el mismo año en que emprende sus primeras obras monumentales.

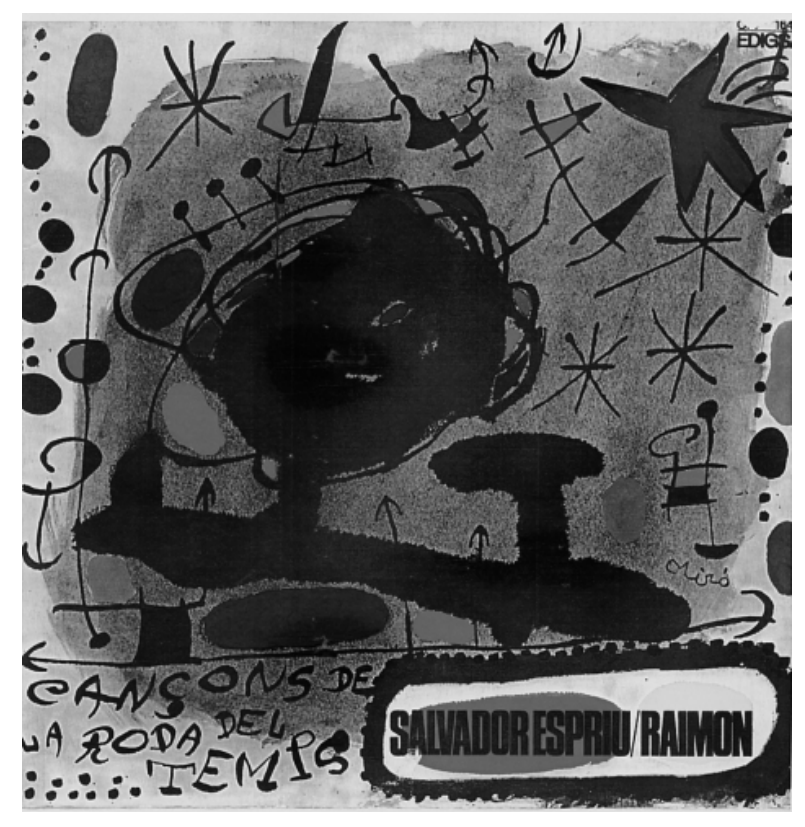

En 1979, ya en la transición democrática, Raimon publica el disco «Quam I aigua es queixa» que contenía de nuevo poemas de Espriu, Ausiás March y textos propios, además de una canción dedicada al escultor Andreu Alfaro. Por segunda vez Miró, gran admirador del cantante, accede a dibujar la portada del disco. En este caso encontramos un Miró más naïf y con uno de sus grandes temas simbólicos: «El pájaro». Es un dibujo más recurrente y menos trabajado que el de la portada del 66, pero igualmente de gran belleza.

De las tres portadas realizadas por Miró quizá sea la relativa a la producción de María del Mar Bonet la que mejor supo rentabilizar su compañía discográfica, al co- 
locarla ocupando portada y contraportada de su disco «Inici de Campana». Me cuenta María del Mar:

"Yo tenía un drama con mi compañía de discos Vocaccio Records, pretendían que grabara una serie de canciones comerciales que no estaba de ninguna manera en la línea de lo que yo quería hacer. De tal manera que con el poco dinero que tenía compré mi carta de libertad. Me fui a Mallorca e hice un concierto en el Auditori de Palma con los poemas de B. Roselló Porcel, un gran poeta que murió joven en la postguerra. Aquella noche, Joan Miró vino a escucharme con toda su familia. Él ligaba mucho su pintura con la poesía y más con las imágenes de los poemas de Roselló, que eran también muy surrealistas. Yo, aproveché el momento y le dije que porqué no me hacía la portada. Me dijo que si. Yo creo que salió del teatro con la idea de lo que iba hacer. Cuando me dio la obra, el marchante que tenía en Palma me prestó el dinero, fui a París a grabar el disco y le dejé el cuadro como aval. A la vuelta, la compañía discográfica Ariola me fichó, me pagó, le devolví el dinero y recuperé ese magnífico trabajo que ilustra la carpeta de mi disco»

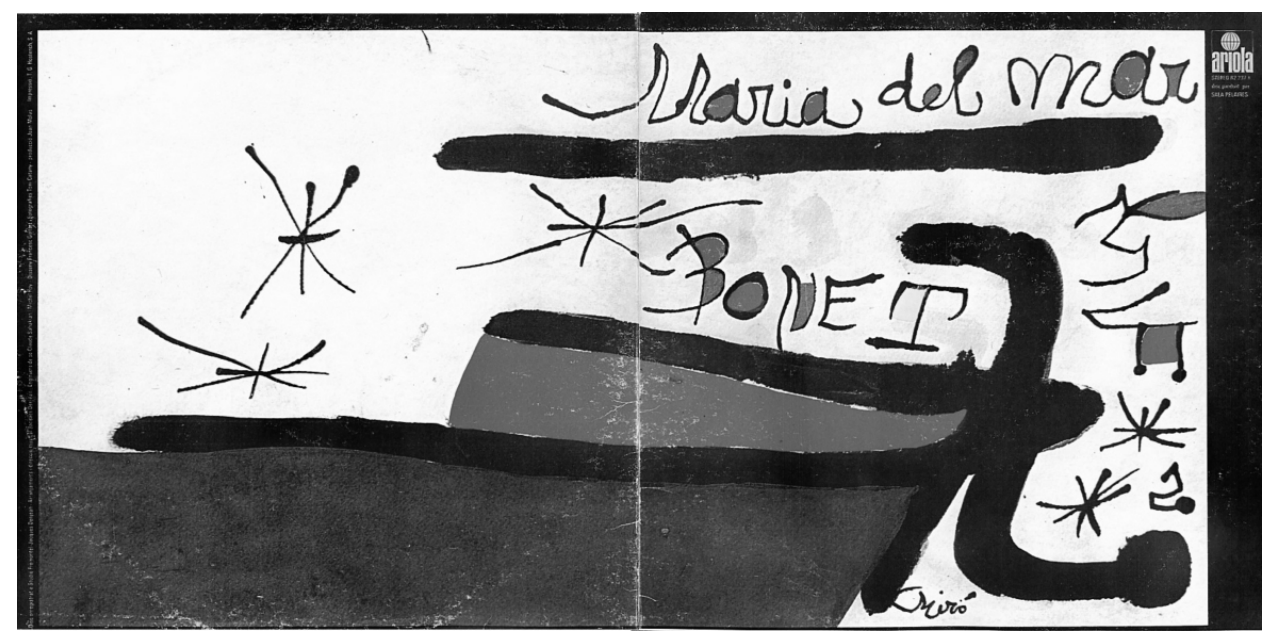

Cuando «La nova canço» empezaba a vivir sus horas más bajas con la llegada de la democracia, se publicó un recopilatorio con alguno de los artistas más populares del movimiento como Joan Manuel Serrat, Ovidi Montllor, Lluis Llach, María del Mar Bonet, Pi de la Serra etc... El disco se titulaba «Junts» (1981) y una obra de Picasso, de 1961, ilustraba la portada de este disco.

Fue la compañía discográfica quien entendió que este dibujo pintado veinte años antes, con rasgos de la pintura neolítica mediterránea, podía potenciar la idea de unir a los mejores cantantes de ese movimiento que había significado tanto en la lucha contra la dictadura. 


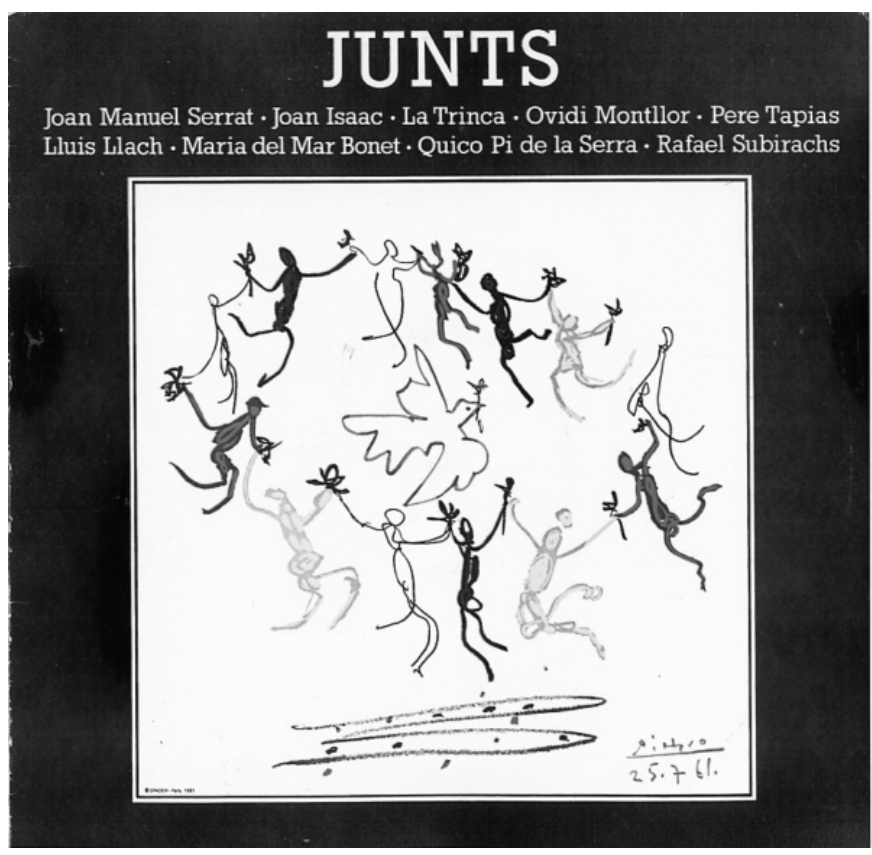

Y no fue la única aportación de Picasso a las portadas de discos. Juan Pardo, músico gallego, se había convertido en uno de los compositores cantantes más populares del país con su grupo «Los brincos» durante la primera parte de la década de los 60. Ya separado de ellos y junto a su compañero Junior preparaba su nuevo lanzamiento, quizá buscando internacionalizarse se lanzó a la búsqueda del pintor malagueño. Así me cuenta en el verano del 2010 como fue su encuentro con Picasso:

"Nos invitó a una paella y yo le llevé una guitarra española de regalo. En la sobremesa, él empezó a preguntarme por algunas nanas gallegas, yo tocaba y se arrancó a cantar conmigo. Él tenía un grato recuerdo de su tiempo en Galicia, le puse la maqueta de la canción Anduriña en la que estábamos trabajando y le gustó mucho. Antonio de Olano que tenía menos vergüenza que yo, le pidió que nos pintara algo para la portada del disco. Él con mucho gusto se dispuso a pintar una Anduriña (golondrina) pero al final lo que pintó parecía más una gaviota».

Sin embargo, a Zafiro, su discográfica, le pareció más comercial una foto de Juan y Junior y el dibujo de Picasso se vio obligado a ocupar la contraportada de «Anduriña», que fue una de las canciones del verano del 68. 


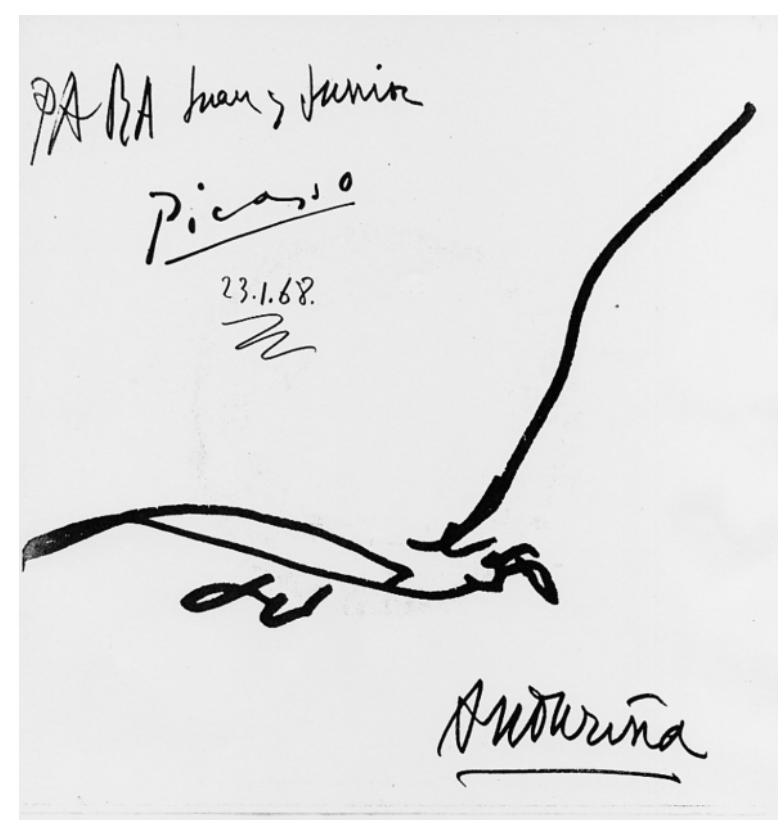

\section{LA VANGUARDIA ESPAÑOLA DE LOS AÑOS 50 Y SU PROYECCIÓN EN LA MÚSICA}

Aunque se considere la 1a Bienal Hispanoamericana de Octubre de 1951 el momento en el que el régimen asume la renovación artística en España y la llegada de la modernidad, no hay que olvidar que fue en la década de los 40 cuando se empieza a gestar una serie de transformaciones plásticas a través de varios fo$\cos ^{9}$. Por un lado, la iniciativa de personajes como Eugenio D ors y su Academia Breve de Crítica y el Salón de los Once. El apoyo de D Ors a este arte que no tenía nada que ver con lo que la academia seguía proponiendo era de alguna manera la aceptación del régimen a ese nuevo camino. Por otro lado el grupo Pórtico en Zaragoza, el movimiento renovador que se inició en el 47 a través de la librería Pórtico y el Casino mercantil, y cuya actividad consistió en la organización de exposiciones de pintura -especialmente la del 48- como «4 pintores de hoy» con Pablo Palazuelo y la programación de ciclos de conferencias artísticas. Igualmente en septiembre de 1948 un grupo de pintores y jóvenes escritores radicados en Barcelona tiran «el dado al siete» y publican el número uno de una revista que comenzó siendo de tendencia surrealista y que poco a poco fue dando el salto al informalismo. Fueron especialmente sus pintores (Tapies, Ponç, Cuixart y Joan Josep Harrats) los que al poco tiempo ya se habían convertido en figuras internacionales del informalismo.

9 Cfr. M. CABAÑAS BRAVO, Política artística del franquismo. El hito de la Bienal Hispano-americana de Arte, Madrid, C.S.I.C., 1995. 


\subsection{Los pintores de «dau al set» y sus portadas de discos}

Los objetivos que este grupo de artistas se habían propuesto desde su formación fueron el afianzamiento del catalanismo cultural y la unión arte-literatura, con lo cual muchos de los artistas de «La nova canço» vieron en los componentes de «Dau al set» sus homónimos en el arte plástico, como es el caso de Raimón al pedir a Tapies la portada para su disco «Per destruir aquel quil Iha desêrt», de 1970, que contenía una selección de poemas de la literatura medieval catalana representada por Ausiás March, Jordi de Sant Jordi y Anselm Turneda.

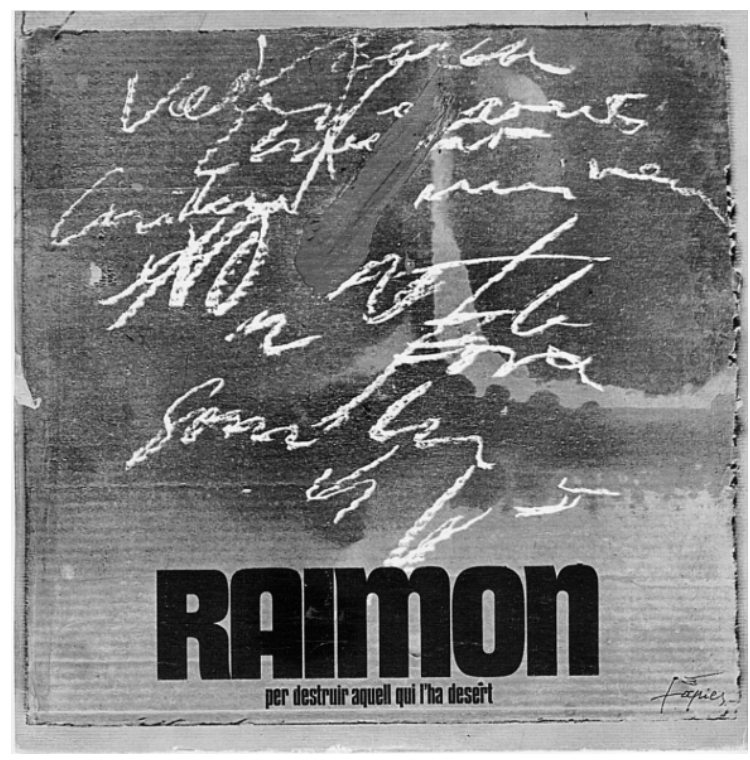

En esos años de represión franquista, Raimón reivindicaba los primeros poemas en valenciano como origen de una lengua perseguida. Para la portada Tapies trabaja sobre cartón. Al principio de esta década había expuesto en medio mundo y recibido premios de los cinco continentes, personalmente se vuelve más crítico y su obra adquiere un mayor tinte político de reivindicación catalanista y de oposición al régimen franquista, momento en el cual utiliza las palabras y los signos. Esta portada es una prueba de ello ${ }^{10}$.

10 Refiriéndose a la expresión y creación de Tapies, J. E. Cirlot puede ayudarnos a comprender la relación entre música y plástica: «Los complejos de líneas, huellas, superficies en contraste y conjuntos cromáticos nacen en virtud de la misma tendencia transformante del espíritu mediante la cual se revelan al compositor sus sentimientos bajo la forma de melodías, acordes o efectos de orquestación. La limitación en la extensión de la imagen corresponde a la limitación del fenómeno emocional. Así como los fondos tienen la propiedad de reflejar las ondas sonoras, también las superficies materiales resultan aptas para reflejar las vibraciones de lo emocional. Ya Kandinsky, en Punkt und Linie zu Fläche, había establecido paralelismos entre formas visuales y acústicas, que se podrían complementar con un análisis de la duración y la extensión» en 
Pero Tapies ante todo es un amante de la música clásica, especialmente la de Wagner. En 1991 cede una obra titulada «Petjada» (huella) para la carpeta de una colección titulada «Compositors de Barcelona»:

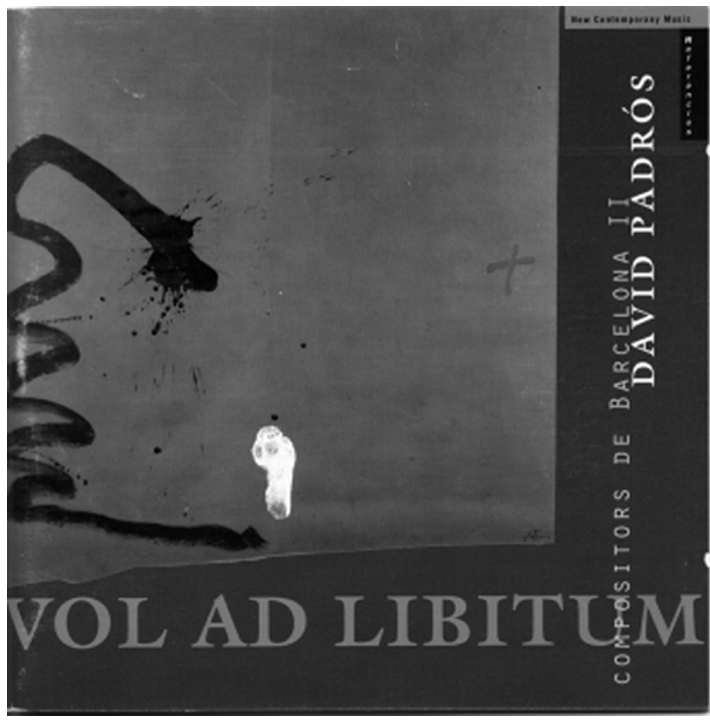

El protagonista de este disco es David Padros, creador serio y meticuloso. Formado fuera de España en armonía, contrapunto y composición, es un músico clásico contemporáneo que encaja perfectamente en el mundo de Tapies. Su obra muy personal tiene a veces inspiración en el pensamiento oriental y se preocupa muy especialmente del espacio, tanto desde una consideración física como personal.

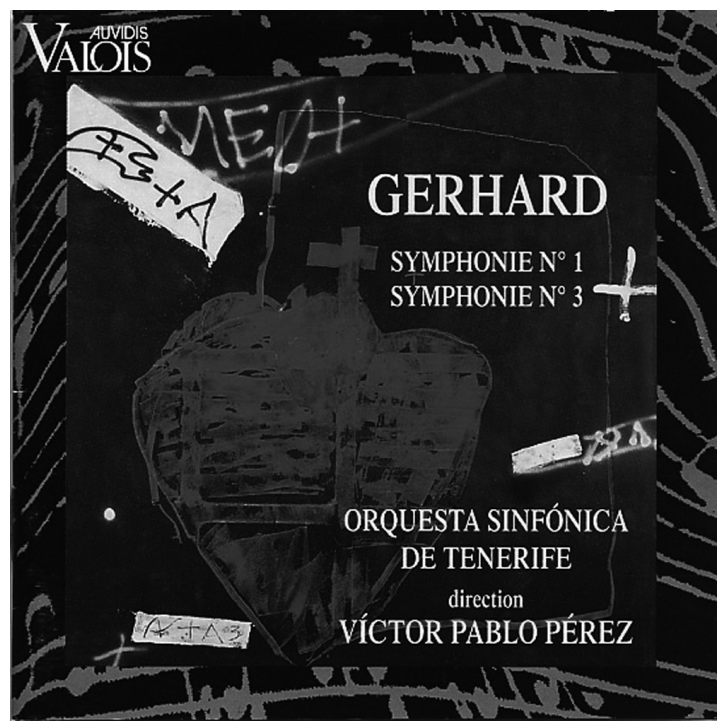


«Cor Roig» es la portada que hace en 1989 para el compositor tarraconés Roberto Gerhard que contiene las sinfonías 1 y 3 interpretadas por la orquesta sinfónica de Tenerife, dirigida por Víctor Pablo Pérez. Gerhard fue alumno de Enrique Granados y Arnold Shoomberg, identificado con la segunda república y la autonomía catalana, la rebelión franquista lo mandó al exilio. Sus obras de 1940 revelan por sus temas explícitamente españoles y catalanes, una añoranza de la patria perdida. Un enorme corazón rojo preside este trabajo de Tapies en homenaje al gran compositor catalán que desde la década de los cincuenta luchó contra el problema cardiaco que acabaría con su vida en 1970.

La más matérica de sus portadas es la que realiza para un disco de Monserrat Martorell donde canta 18 canciones tradicionales de un marcado carácter nacionalista, bajo el título de «Cançons tradicionals dels Paisos Catalans».

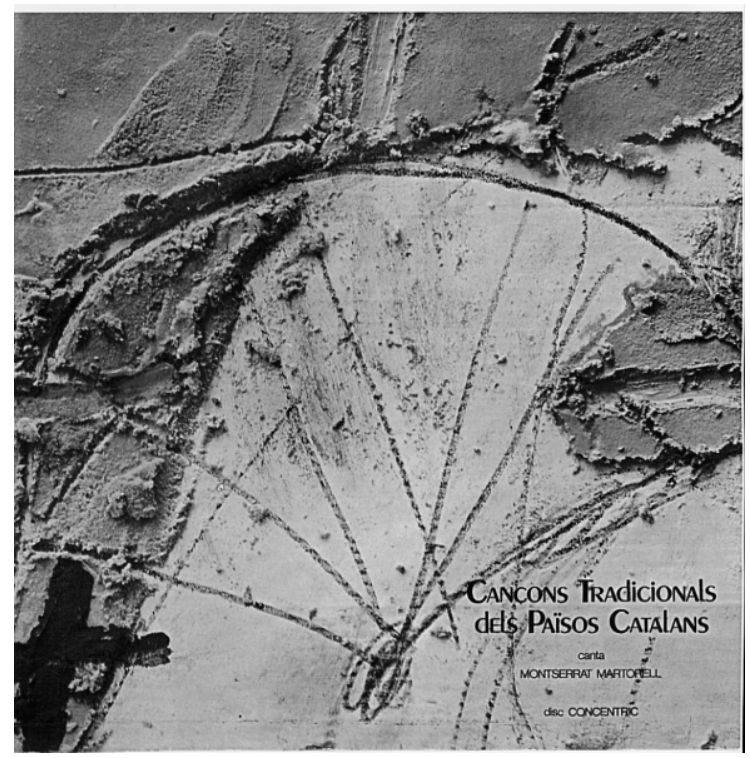

Otros trabajos de Tapies incluyen la portada de la «Coral Carmina» en su décimo aniversario y la que realizó al grupo corso I Muvrini en su disco «Umani».

Otro artista de «Dau al set» es Modest Cuixart quien realiza la carpeta del cantautor Xabier Ribalta en su disco «Altes parets de somni» y la del disco «Silencis» de Max Sunyer, máximo exponente del jazzrock catalán de los 80 .

\subsection{Guinovart y otros artistas de su generación}

Guinovart, Mompó, Alfaro, Hernández Pijoan, Rafols Casamada, Palazuelo y Juan Genovés, grandes nombres del arte español del siglo XX, vivieron con plenitud la década de los 50 , y su huella se puede encontrar en cada una de sus 
obras. Todos hicieron portadas de discos. Tres de ellos para el mismo artista: Xabier Ribalta, cantautor leridano que junto a Raimón es quien más utilizó la pintura para ilustrar su música. Guinovart, Mompó y Hérnandez Pijoan son algunos ejemplos.

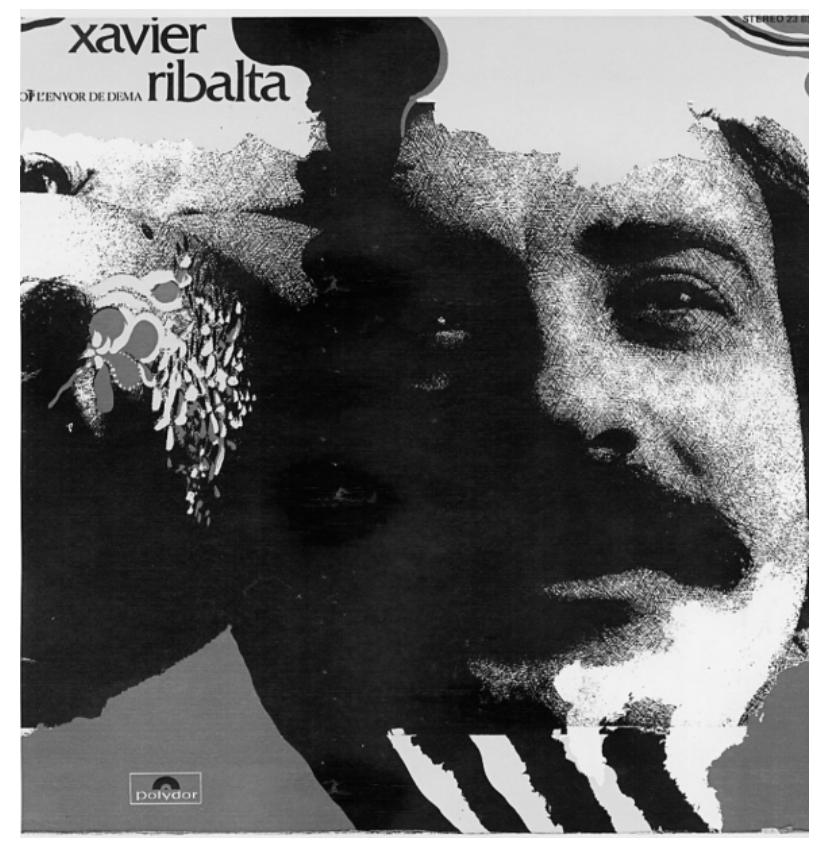

Mompó en "Xabier Ribalta canta a Joan Maragall», de 1985, muestra lo mejor de su pintura mediterránea llena de color, impresiones y sentimientos.

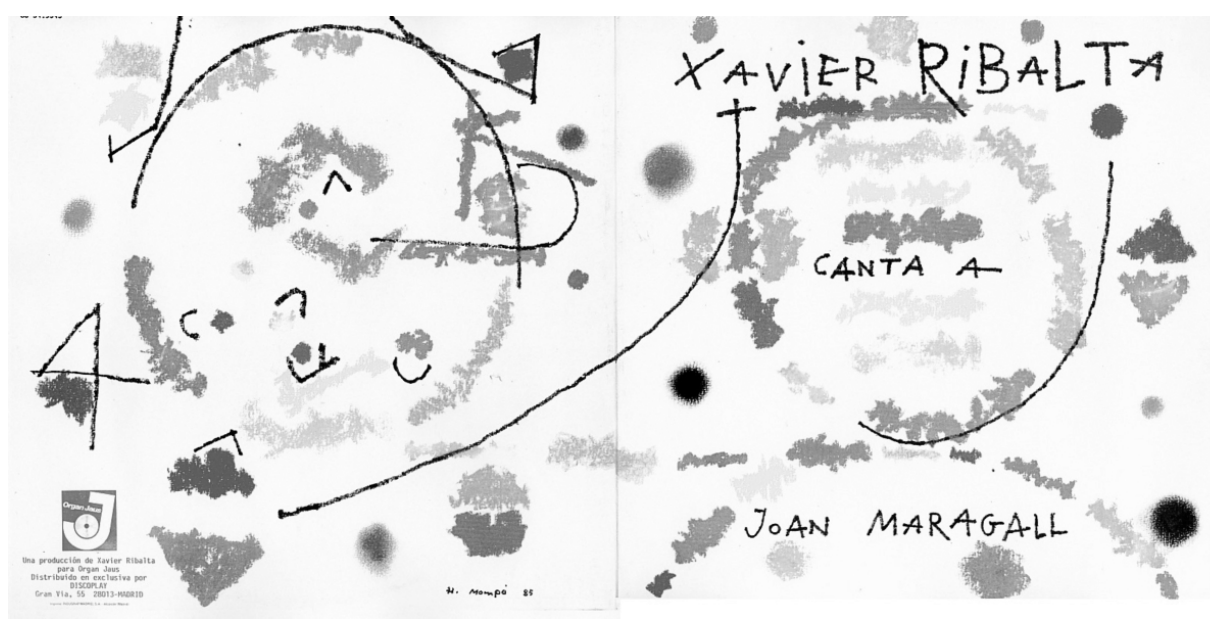


Y Hernández Pijoan pinta la carpeta del disco que Ribalta grabó en el Olympia de París en 1967.

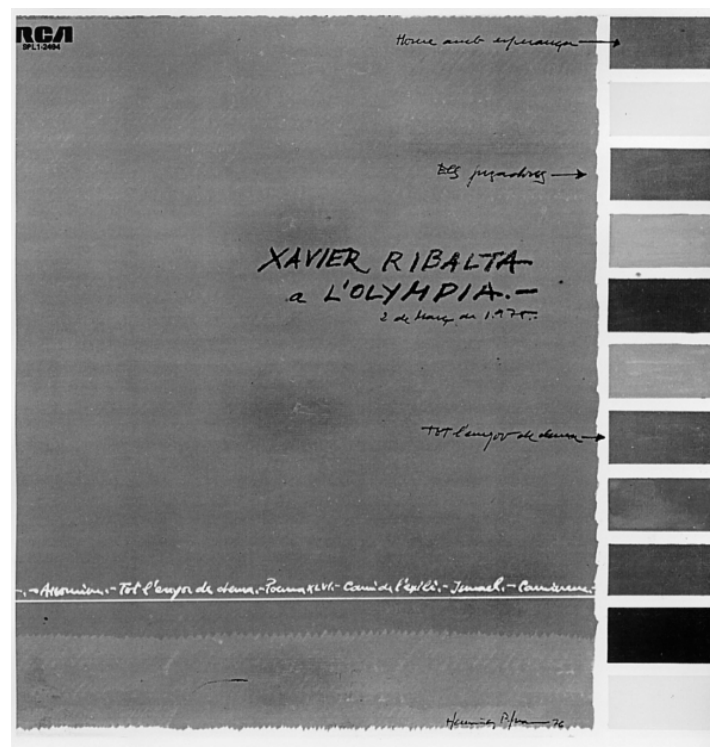

Como buena parte de su obra, la pintura de Hernández Pijoán para este disco está basada en las investigaciones sobre el color. Hay una tabla de colores en el margen derecho con indicaciones sobre el color verde. En esta etapa Hernández Pijoán estaba centrado en el concepto del paisaje o como el decía en los «momentos de un color para definir un paisaje».

Juan Genovés, un año mayor que Hernández Pijoán, fue además compañero y amigo de Mompó. Realiza la portada para el disco de Adolfo Cedrán titulado «Silencio", de 1970, donde utiliza un lenguaje pictórico de singular realismo y fuerte denuncia social. Son hombrecillos despersonalizados, insignificantes, huyendo hacia su propio fin. Es el año del «Proceso de Burgos», de ahí que la portada sea una mirada a la masa desde dentro de una celda, mientras que el interior del disco está ilustrado directamente con un fusilamiento.

Adolfo Cedrán pertenece al grupo «Canción del pueblo», donde también estaban Hilario Camacho, Elisa Serna, y Rosa León. Actualmente es catedrático de Física Nuclear en la Universidad de Alicante. Nos cuenta José Ramón Pardo, crítico musical y colaborador en la grabación de este disco que «Genovés tenía miedo a que la galería Malborough con la que acababa de firmar le pusiera algún impedimento para realizar la portada, le apetecía tanto el proyecto que decidió jugársela sin pedirles permiso». El disco fue autorizado por el régimen para salir a la venta pero no para su radiación. 


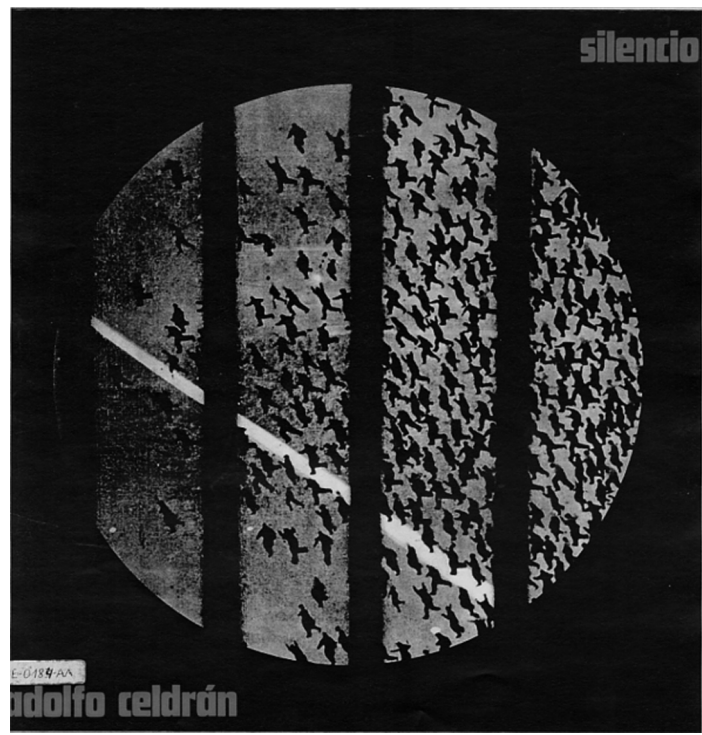

Hemos dejado para el final de este apartado una portada del genial Pablo Palazuelo que ilustra el disco de un joven músico contemporáneo llamado Jose María Sánchez Verdú y su albúm «Arquitecturas de la ausencia». El músico comentó a propósito del artista:

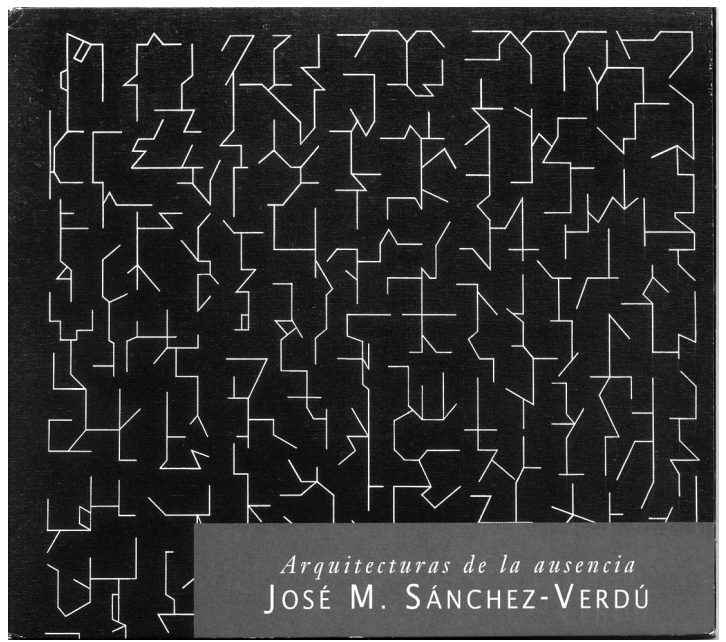

«Para mí fue un trascendental encuentro conocer la obra pictórica de Pablo Palazuelo y ver sus propuestas y soluciones ante el desarrollo del material que yo llevaba tiempo buscando y casi ya recorriendo. Ese uso de la geometría, de formas laberínticas, reiteraciones de patrones etc., crea una energía impresionante, indescriptible [...] En mi pieza, esa forma de articulación está cercana no sólo a esa concepción geométrica de materiales que se reiteran y varían [...], sino también 
a la repetitio en el arte de la retórica: figuras retóricas que nacen y se generan por adición. La variación es el elemento antitético que modifica la presencia de la repetición... Energía, laberinto, peregrinación».

\subsection{El paso}

El Paso supone la plena introducción del informalismo en España a finales de los 50. El blanco, negro y rojo son las referencias cromáticas de artistas como Antonio Saura, Rafael Canogar, Manolo Millares o Manuel Rivera, y es lo que se ha venido llamando «la negación del color». Es curioso que, a diferencia de lo que ocurrió con los pintores de «Dau al set» y su estrecha relación con los músicos, en este grupo sólo esté representado Antonio Saura con dos trabajos, uno para el cantautor maño Labordeta y otro para Paco Ibáñez, así como Manuel Millares para la portada de un disco de su hermano Agustín. ¿A qué se debe la escasa relación de estos pintores con la música? Una razón es, sin duda, la falta del aspecto nacionalista que hemos visto sobre todo con los pintores y músicos del área mediterránea, donde no solo su historia, sino sobre todo la lengua, fueron un componente cultural de unión a través del cual todos se sintieron identificados.

Aquí es Paco Ibáñez, con su album titulado Paco lbáñez 3 «España de ayer, hoy y siempre», quien recoge una recopilación de poetas casi todos de la Generación del 27, a excepción de clásicos como el Arcipreste de Hita o Jorge Manrique, este último con «Las coplas a la muerte de su padre».

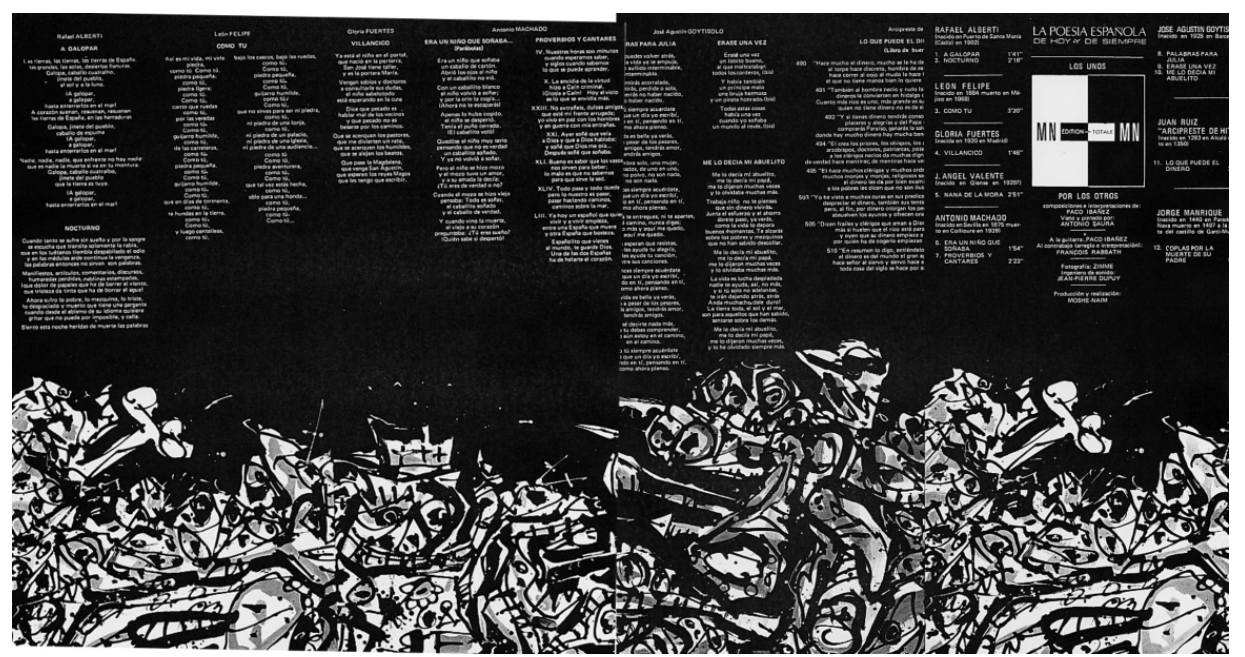

El trabajo de Saura se incluye a modo de tríptico en la carpeta interior del disco. Es un dibujo más en el estilo de lo que solía hacer en los papeles y la obra gráfica. 
La última de las aportaciones al mundo del disco por un componente del grupo «El Paso» es quizá la más diferente y original de todas. Es una obra muy desconocida, una acuarela titulada «Agustín en Canarias» y hace referencia a un pasaje biográfico del hermano del artista, Agustín Millares Sall.

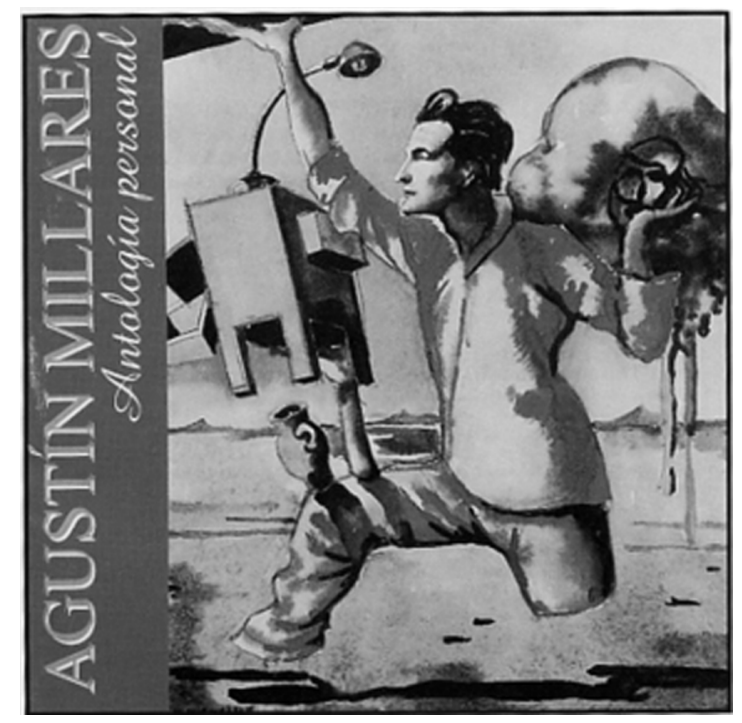

Fue utilizada para la portada del disco de Agustín y Totoyo Millares «Antología personal» producido por el centro de la Cultura Popular Canaria. Nada tiene que ver con el Millares de las arpilleras, esta acuarela está más cercana al mundo surrealista que a la abstracción promovida por el grupo «El Paso». Como anécdota esta obra fue subastada en la galería Ansorena de Madrid enJulio de 2007.

\section{LOS 60: ¿LA DÉCADA PRODIGIOSA?}

Beatles, Rolling Stones o Doors, mayo del 68, la liberación sexual, Kennedy, el hombre en la Luna y mucho más ocurría en estos años, mientras en España estábamos con el 600 , los guateques y la música «ye yé». Por lo tanto la pregunta del encabezado se podría responder con un «depende». El retraso cultural aún con el plan de estabilización a toda máquina nos daba nuestra singular década prodigiosa. Sí, los Beatles venían a tocar a Madrid y Barcelona, pero muchos fans no llegaban a verlos al ser detenidos por la policía. Ante este cuadro no creo que los españoles estuvieran muy preocupados por la narrativa del Arte Moderno de Clement Greenberg ${ }^{11}$ o las teorías de Arthur C. Danto ${ }^{12}$ sobre la llegada

11 C. Greemberg, Arte y cultura, Barcelona, Piados, 2002.

12 A. Danto, Después del fin del arte. El arte contemporáneo y el linde de la historia, Barcelona, Paidos, 1999. 
del Pop. Lo que si estaba claro era el agotamiento de la tendencia informalista y aunque de una manera tímida acabaron llegando los ecos del Popart.

Si Andy Warhol representó hasta la saciedad los mitos más sobresalientes de la sociedad de consumo norteamericana, el «Equipo Crónica» mezcló ciertos mitos de la historia moderna de España con otros del momento. Así era fácil ver al Conde Duque de Olivares ataviado con el guante del boxeador más popular de la España de los 70.

Las cinco portadas realizadas por el «Equipo Crónica», cuatro para Raimon y una para Ovidi Montllor, tienen en común que fueron hechas para discos a 45rpm, lo que era conocido como single. Hasta ahora todas las portadas vistas en este trabajo, excepto la de Picasso para Juan y Junior, eran de discos Lps o 33rpm. Optar por 45rpm era lógico puesto que el single fue el instrumento más conocido de la música Pop, dos canciones de uso rápido que se editaban en ese formato, a mejor precio y con más tirada, algo parecido a la filosofía de marketing de las serigrafías del Popart.

En los cuatro singles del «Equipo Crónica» para Raimon está prácticamente una muestra completa de su repertorio. Concretamente la portada del single "Canço de la mare» y «Diguen no» podemos ver a parte de las glorias de la historia de España.
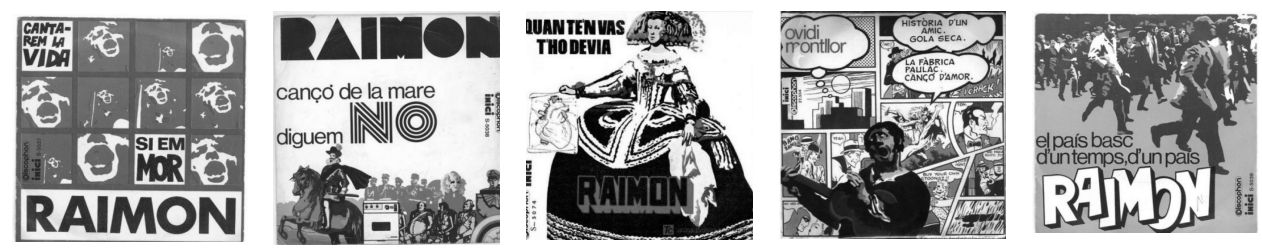

Eduardo Úrculo también realizó una fantástica portada para un disco homenaje a Lorca con artistas de la talla Leonard Cohen, Paco de Lucía, Moustaki etc...

\section{5.- LOS 80. ¿OTRA DÉCADA PRODIGIOSA?}

Pues, parece que sí. A principios de los 80 la relación músicos, pintores, fotógrafos y cineastas es la más fructífera hasta el momento en la historia contemporánea española. Ahora todos son de la misma generación. No fue el caso de los artistas de los 60, utilizados de una manera muchas veces nostálgica ilustrando discos veinte años después por haber una conexión lingüística y cultural como hemos visto. No, en los ochenta los pintores estaban en el mismo club asistiendo al momento creativo de los músicos y viceversa. Ambos provocaron con su obra una ruptura total de aquel arte de carácter político que había caracterizado, sobre todo, la España de los 60 y 70. Esta nueva generación de músicos «no quiere ver a un cantautor ni en pintura» mientras que estos pintores quieren nuevas experiencias artís- 
ticas, alejadas de los estilos que les precedieron. Así pues, y como dice Francisco Calvo Serraller, antes de revisar algunas de las obras de estos artistas hay que situarse en «la purga de los 70» donde el retorno a la democracia trajo consigo nuevas realidades, especialmente en el ámbito de las infraestructuras culturales ${ }^{13}$.

Podemos decir que Luis Gordillo y Juan Aguirre son los preparadores del clima ideológico que inspiraría a gente como Guillermo Pérez Villalta, Carlos Alcolea, Manolo Quejido, Carlos Franco, Chema Cobo, Sigfrido Martín Begué, Juan Navarro Baldeweg, Alfonso Albacete etc...sin olvidar a los artistas del área mediterránea como Mikel Barceló y Mariscal, entre otros.

Guillermo Pérez Villalta llegó a Madrid en 1968, pero es en la década de los 80 cuando está en su auge creativo. Parte de sus amigos formaban la élite de los grupos de Pop, que cada noche solían actuar en el Club Rockola. Sus cuadros de fuerte colorido y luminosidad representan personajes que se mueven dentro de complejas escenografías teatrales y arquitectónicas. Ha declarado recientemente: «Mi obra es hija del Barroco y la Psicodelia».

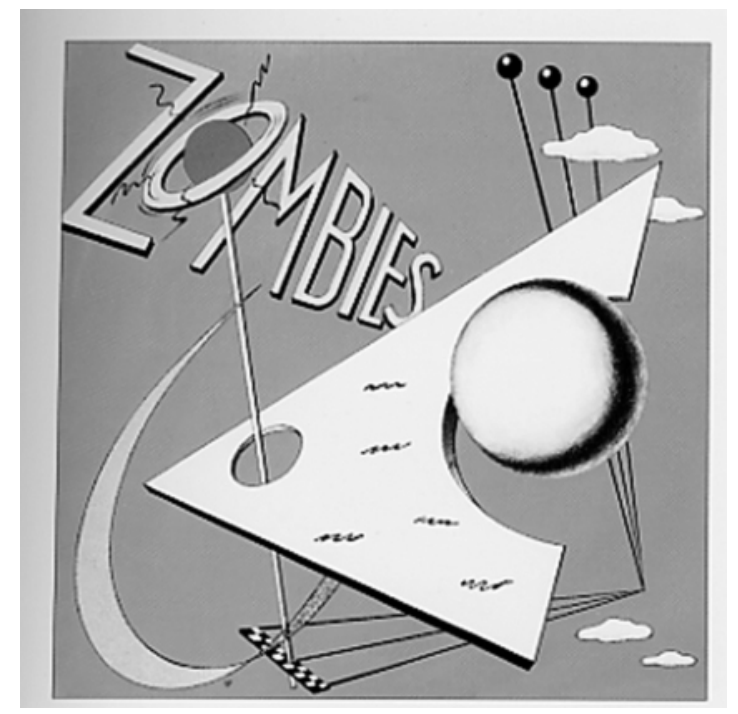

Pérez Villalta nos habla de su relación con las portadas de discos, su pintura y su momento artístico, en una conversación tranquila en su casa de Tarifa, el 10 de Agosto de 2010:

\section{— ¿Cómo hiciste la portada para «Los Zombies»?:}

- Hicimos tres o cuatro bocetos y al final quedó esto que es una esfera dibujada en acuarela que recorté y monté sobre ese fondo que sí está pintado entero.

${ }^{13}$ F. Calvo Serraller, España, medio siglo de arte de vanguardia, Fundación Santillana. 
Quería hacer algo que tuviera un aire tecno-pop como de "cachondeo", como una película de ciencia ficción de los años 50.

— ¿Y la portada de «Así canta nuestra tierra»?:

- Esta es muy reciente y está en la onda de lo que he hecho en los últimos años. Quería utilizar todos los tópicos de la navidad, pero con una idea nueva. En vez de huir de ellos me metí de lleno en ellos, pero cambiándolos. Diseñe esa estrella de Oriente tan absurda, el pino de navidad que en el fondo es como las esculturas que hago ahora. Quedé muy satisfecho de esa portada, porque la miras y dices: "sí, es de Navidad». Y por otro lado tiene un toque moderno y psicodélico».

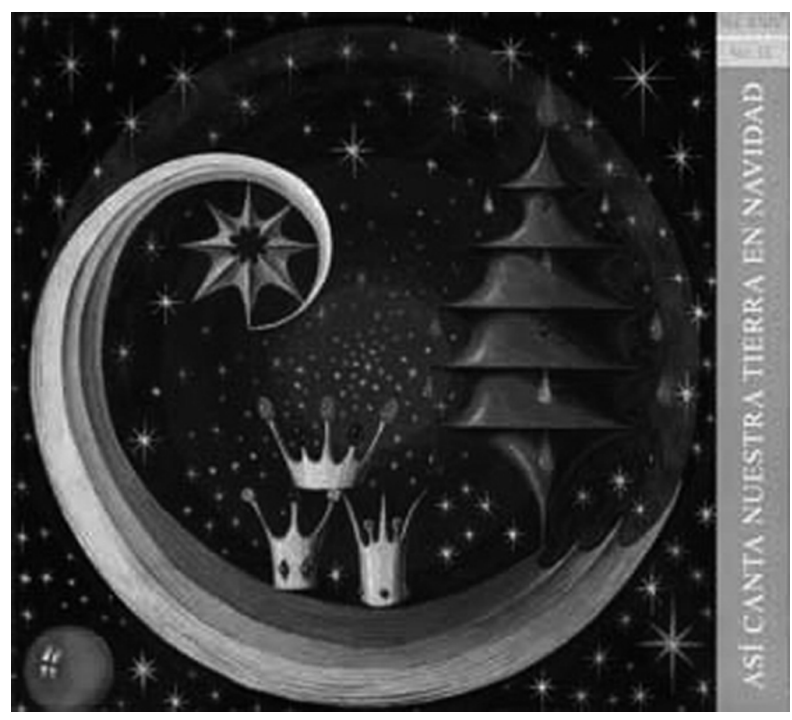

— ¿En que momento se encuentra tu pintura ahora en 2010?:

-En un momento de ensoñación melancólica. Todo está más difuminado, menos claro, tengo una cierta sensación melancólica... Difícil de explicar, ahora mismo tengo la sensación de un extraño pre-romanticismo como del final del rococó y principio del romanticismo. Tengo la sensación de que se acaba un mundo y comienza otro. Una especie de huida constante a un mundo imaginario, quizá porque el mundo ahora tiene muchas cosas terribles, muchas cosas terribles...

- ¿Cómo ves en este momento de la industria discográfica y las nuevas tecnologías, las portadas de los discos?:

-Yo creo que el paso del $L p$ al Cd supuso para el objeto una pérdida muy grande. El formato de $31 \mathrm{~cm} \times 31 \mathrm{~cm}$ era bellísimo. Yo llegué a comprar discos sólo por la portada y comprarlo como un objeto de arte. A pesar del tamaño del Cd creo que se siguen haciendo cosas bonitas. 
Juan Navarro Baldeweg reconocido arquitecto realizó una de las portadas más interesantes del Pop español para el grupo «Radio Futura» en su álbum «La canción de Juan Perro», de 1987:

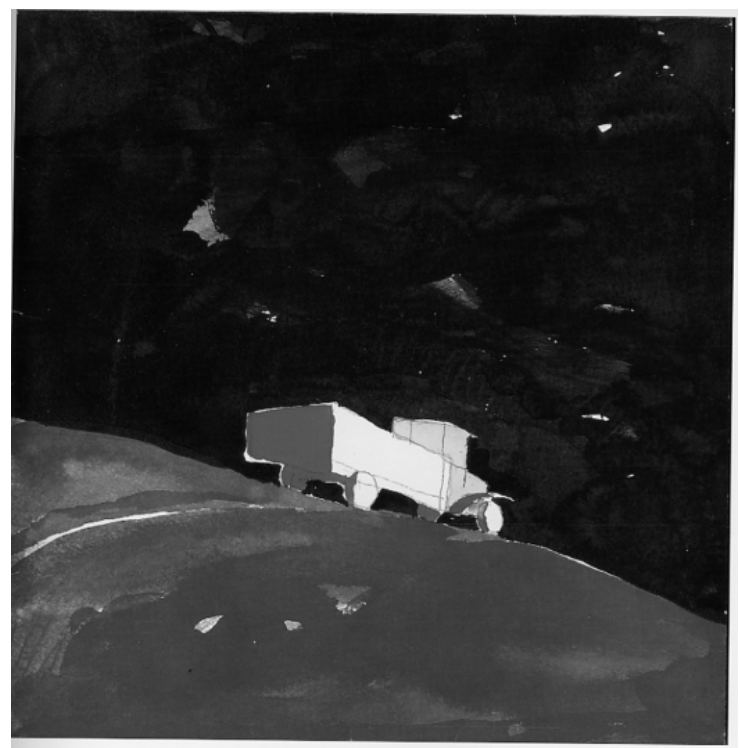

Cesepe es otro dibujante muy unido al mundo de» la movida madrileña» y gran amante del Pop y el Rock. Dos interesantes portadas, una para el artista hispanofrancés Pascal Comelade y su disco «El primitivismo», de 1987, y otra para el grupo Ketama, de 1985.

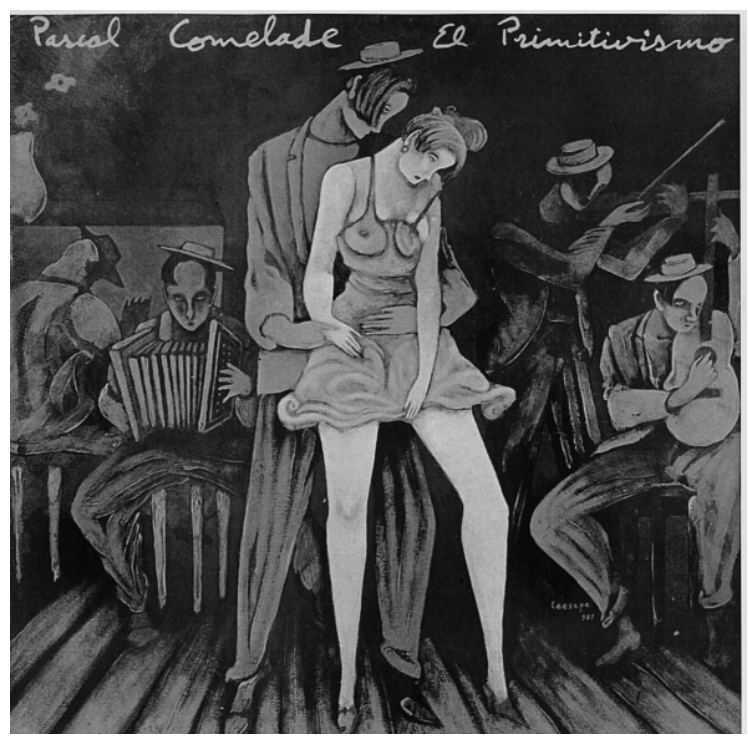


Javier Mariscal ha comentado en más de una ocasión que le hubiera gustado ser músico, pero que sus nulas cualidades lo inclinaron hacia la pintura y el diseño. Varios ejemplos de su amor a distintos tipos de música son estas portadas, una para la super vedette «Rosita Amores» en un disco homenaje a esos artistas de la postguerra que pasaron por el teatro Alkazar de Barcelona y otras para la Orquesta Mirasol, Gato Pérez o la Fiesta Independiente.

Otro pintor catalán que durante años dibujó para los comics más importantes de la época es Nazario. Artista contracultural y pieza clave de la «movida barcelonesa» de finales de los 70 y principios de los 80 , retrata como nadie los bajos fondos de Barcelona en «Anacorma» su serie más conocida. Sus comienzos estuvieron ligados a Mariscal con quien funda el «grupo Rrollo». Con Ceesepe trabajó en un libro sobre Lou Reed y fue el propio cantante quien utilizó la portada del libro para uno de sus discos, con el consiguiente problema legal. Destacan las dos portadas realizadas para el grupo sevillano de Rock «Dogo y los Mercenarios», especialmente «Mala reputación» que es un ejemplo paradigmático del estilo y el mundo de Nazario.

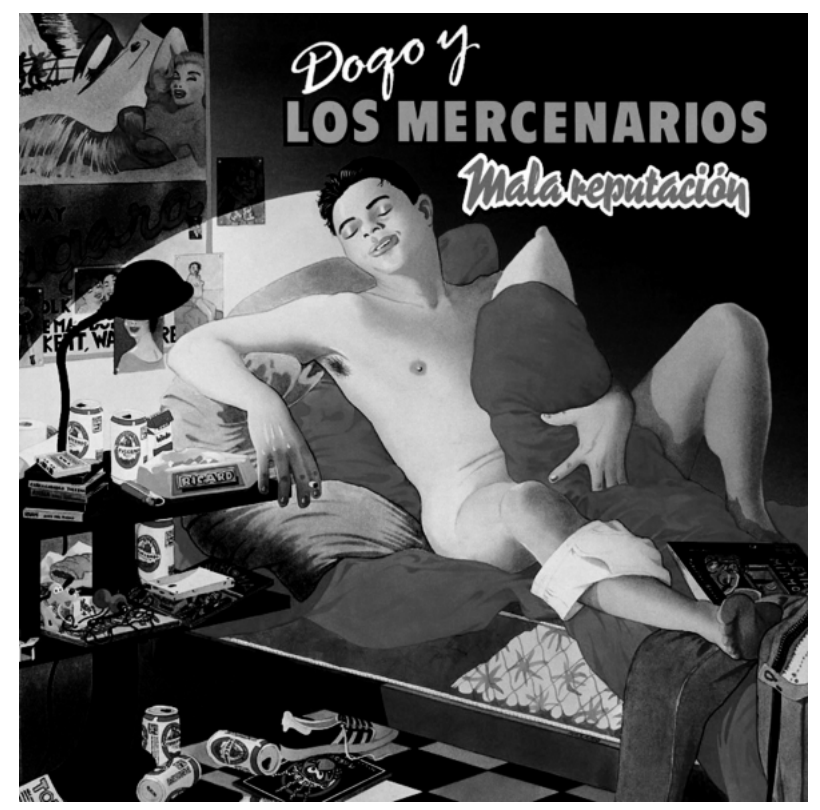

Mikel Barceló es otro amante de la música. Su primera portada la firma tres años después de la Documenta de Kassel para un grupo mallorquín de escaso éxito, algo que repetiría para otros artistas como Agustí Fernández, Biel Mayoral o Antoni Caimari. La portada más popular es la del disco «Potro de rabia y miel»» de Camarón de la Isla. Más tarde, en 1991, volvería al mundo del flamenco con Rancapino. 


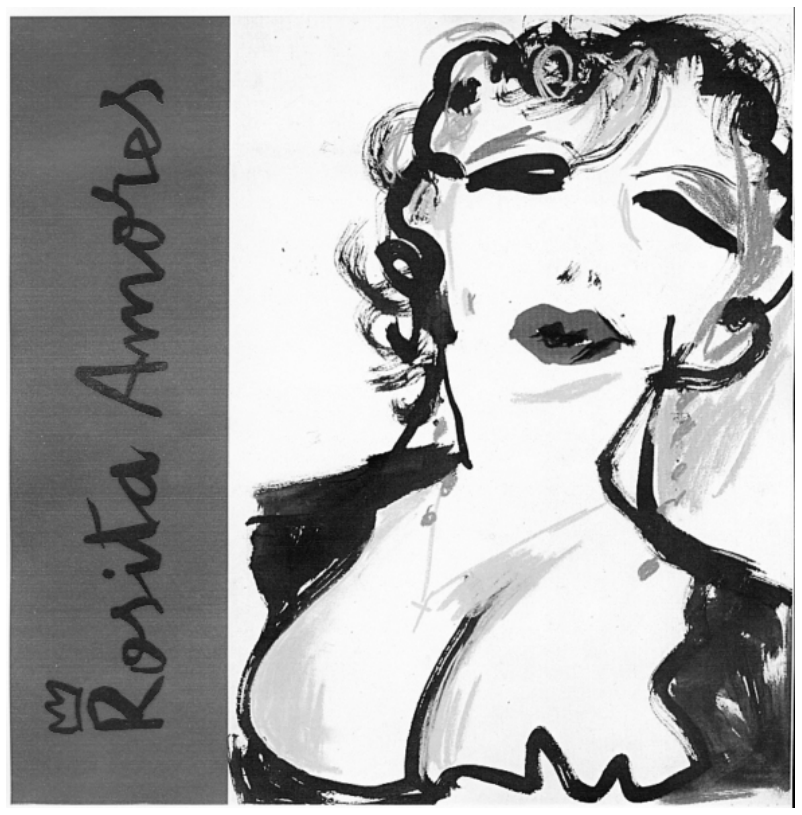

\section{6. «SU DISCO FAVORITO»}

Es el título de una interesante exposición que realizaron en los 80 Quico Rivas y Pablo Sycet y que recorrió la geografía nacional durante varios años ${ }^{14}$. Cada artista trabajó en formato LP la portada del que fuera su disco favorito con la idea de satisfacer el encargo que nunca le hicieron. La inauguración fue en la galería Antonio Machado de Madrid. A continuación tres interesantes ejemplos de cómo estos pintores mimaron la funda de «su disco favorito».

Alfonso Albacete realizó, en técnica mixta sobre papel, una portada de un disco de Manolo Caracol, de 1987; nos cuenta en su historia de la Elipa en Madrid como se inspiró para este trabajo.

— ¿Porqué la hiciste sobre Caracol? ¿Te gusta mucho el flamenco?:

- Si. Me gusta mucho el flamenco, estuve dudando porque otro de mis discos favoritos era «Ziggy Stardust» de David Bowie, pero Guillermo Pérez Villalta me dijo que la iba hacer él.

— ¿Cómo se te ocurrió la idea de este cuadro?:

${ }^{14}$ P. Sycet, Los colores de la música, Madrid, Fundación Provincial de Artes Plásticas-Diputación de Córdoba, 2003. Cfr. Igualmente el catálogo de la exposición Formas y colores de la música, Madrid, Comunidad de Madrid, 2009. 
- En aquella época estaba yo pintando unos cuadros que se llamaban cuadros andaluces y había uno titulado "Tormenta entre Málaga y Córdoba», en esa serie intervenían algunos elementos, como la figura central del «Tributo» de Masaccio en la que el personaje une dos situaciones. A mí siempre me había gustado la idea de unir dos situaciones, entonces los cuadros aquellos de la tormenta entre Málaga y Córdoba eran como un cambio de paisaje en una tormenta incluí esa figura.

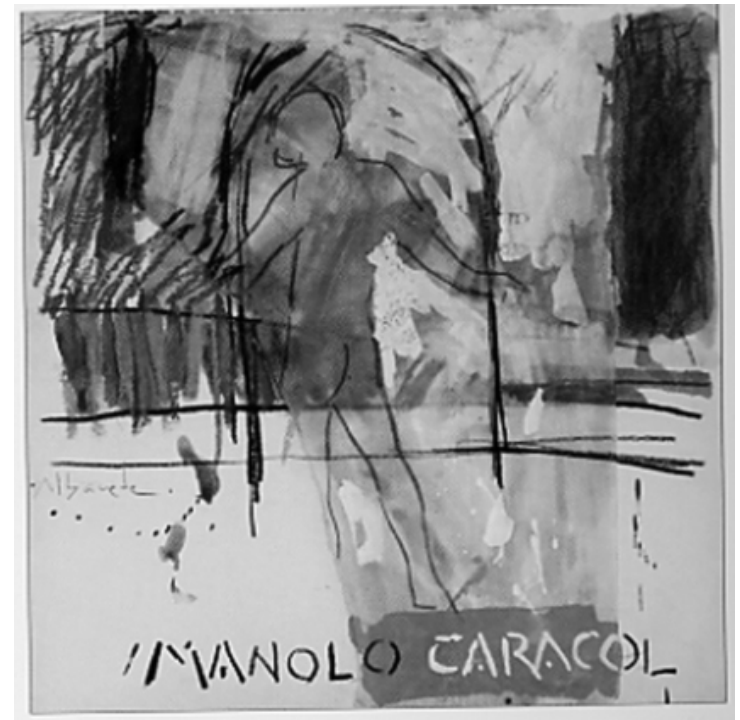

— ¿Este cuadro mezcla lo figurativo y la abstracción?:

-Si. En aquella época tenía más tendencia a la abstracción, Yo siempre me he movido en la línea de que la figuración se reciba como una abstracción y al revés hacer una abstracción figurativa. trabajo:

- Me has comentado que coleccionas algunas de las portadas incluidas en este

-Sí, tengo las de Miró para María del Mar Bonet y algunas de Tapies para Raimón. Era muy habitual que en los discos que se consideraban cultos interviniera un pintor. Es curioso porque la situación que se produjo al principio de los 80 era también ese ambiente, quizá porque había muchos músicos y artistas plásticos mezclados. Ellos venían a nuestra inauguración y nosotros íbamos a sus conciertos y además había gente que practicaba las dos cosas, como el caso de Carlos Berlanga. Había mucha conversación mezclada...

— ¿Cómo te sientes dentro de la etiqueta de «la nueva figuración»?:

-Bueno, ya sabes... yo tuve una formación muy clásica, empecé con nueve años asistiendo al estudio de Juan Monajil que era de la generación del 27 y for- 
maba parte de las misiones pedagógicas que confiaban los cuadros del Prado para los museos ambulantes. Eran él, Ramón Gaya, Roberto Vicente, y yo empecé a pintar ahí. La educación que recibí fue de una pintura muy natural. Luego cuando Ilegué a Valencia con 17 años me encontré de golpe y porrazo con el Equipo Crónica y el Equipo Realidad y yo intenté mezclar aquellas dos cosas. Cuando llegué a Madrid, como estaba en la Escuela de Arquitectura, conocí a Ignacio Gómez de Liaño, a Nacho Criado y a mi aquello me fascinaba, hice instalaciones y fotografía... Pero mi idea de aquella época era mezclar todo lo que pillaba, mi formación clásica, el pop, las instalaciones... eso me colocó en una situación que sigue hasta hoy, que es esa especie de darle vuelta a los elementos, coger actuaciones que se han utilizado para el abstracto y forzarlas a que vuelvan a tener representación figurativa y viceversa, coger cosas que tradicionalmente se han representado de una forma figurativa y darle una historia abstracta.

—Si tuvieras que hacer hoy una portada, ¿A quién te gustaría?:

- Sin duda alguna a Laurie Anderson, esa artista neoyorkina, desde que la vi en directo me fascina.

Para esa misma exposición de «Su disco favorito» otros artistas hicieron sus portadas, traemos a este trabajo las más significativas. José Manuel Broto realiza una portada para el disco de Bruce Springsteen, "The river», uno de los más grandes de la historia del Rock. Podemos comparar la original publicada por su compañía Sony en 1980 y la de Broto, muy en la línea de su pintura de los años 80, donde el color resulta fundamental.

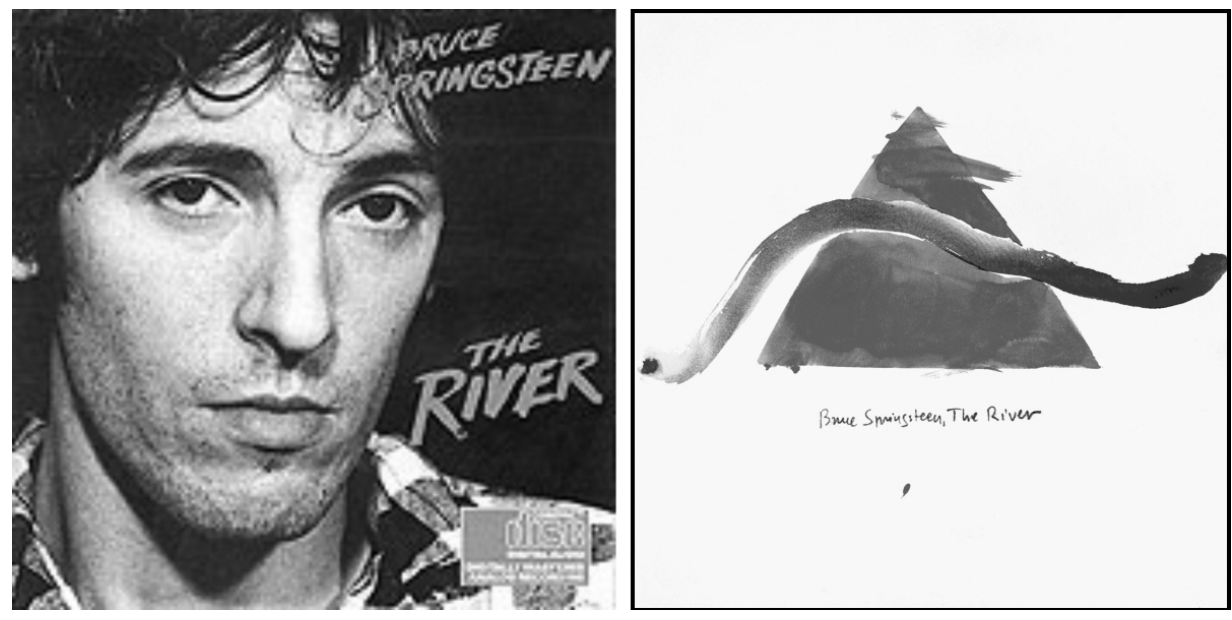

Dis Berlín es otro de los artistas vinculado a la modernidad artística española contemporánea y a la «movida madrileña». Él confeccionó una portada de su disco favorito para la que fuera componente de la Velvet Underground. Nico debutó en solitario con este disco titulado «Chelsea girl», en Octubre de 1967, que 
además es una referencia a la película de Andy Warhol donde ella participaba. Musicalmente es un disco a medio camino entre el folk y el pop de los 60 . A continuación la original y la imaginada por el genial Mariano Dis Berlín.
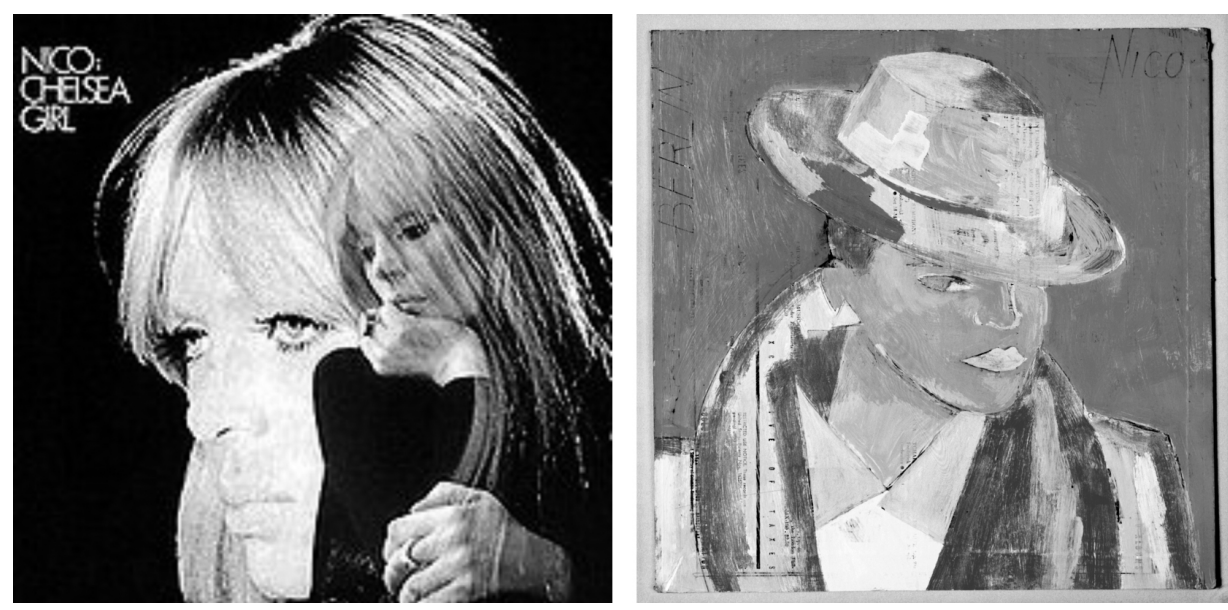

\section{MÚSICOS PINTORES, SUS PROPIAS PORTADAS Y OTRAS OBRAS}

Son muchos los músicos que alternan la pintura entre sus creaciones artísticas. Algunos de ellos ya sólo se dedican a la pintura como José María Cano, otros lo alternaron casi al 50\% como Carlos Berlanga o Luis Eduardo Aute. Manolo García, componente de uno de los grupos más importantes del Rock español «El último de la fila», lleva pintando y dibujando más de veinte años, en hoteles, carreteras y tiempos de descanso. Víctor Aparicio, María Jiménez, Alejandro Sanz, Camilo Sesto y otros muchos, combinan sus instrumentos con lápices, ceras, pinceles, etc...; en el siguiente repaso conoceremos sus obras y su manera de desarrollarla.

Carlos Berlanga: Compuso algunas de las canciones que forman parte de la memoria colectiva de la España de la transición. Desde finales de los 70 se convirtió en uno de los personajes clave del movimiento juvenil que transformó Madrid en una ciudad alegre, divertida y con gran actividad cultural. Formó parte de grupos como «Kaka de luxe» «Alaska y los pegamoides» o «Alaska y Dinarama». Escribió canciones como «El bote de colón» o «A quien le importa». Pero él tenía un talento multidisciplinar y como artista plástico —-posiblemente ensombrecido por la música- desarrolló una larga carrera que recientemente ha sido reconocida con una excelente exposición y libro titulados «Viaje alrededor de Carlos Berlanga»15 Ahí se puede comprobar su talento y versatilidad con mas de cien obras que van desde las primeras piedras vendidas en el rastro de Madrid a dibujos en todo tipo de soportes y técnicas.

${ }^{15}$ Catálogo de la exposición Viaje alrededor de Carlos Berlanga, Madrid, Factoría del Autor, 2009. 
Sobre su manera de pintar, dice el artista granadino Julio Juste: «Su pintura delata una preferencia por la síntesis de la imagen. Prefiere el esquema a la imagen detallada, heredero de las simetrías matemáticas y las transformaciones topológicas, que aplicaron al arte los pintores de la vanguardia de comienzos del siglo XX, como Cézanne, Picasso o Matisse. Carlos obtenía excelentes resultados reduciendo a lo esencial sus imágenes: le bastaban unos cuantos cortes de papel para que surgieran retratos fácilmente reconocibles» ${ }^{16}$. A continuación se reproducen algunas de las carátulas que hizo para los tres grupos de los que formó parte:
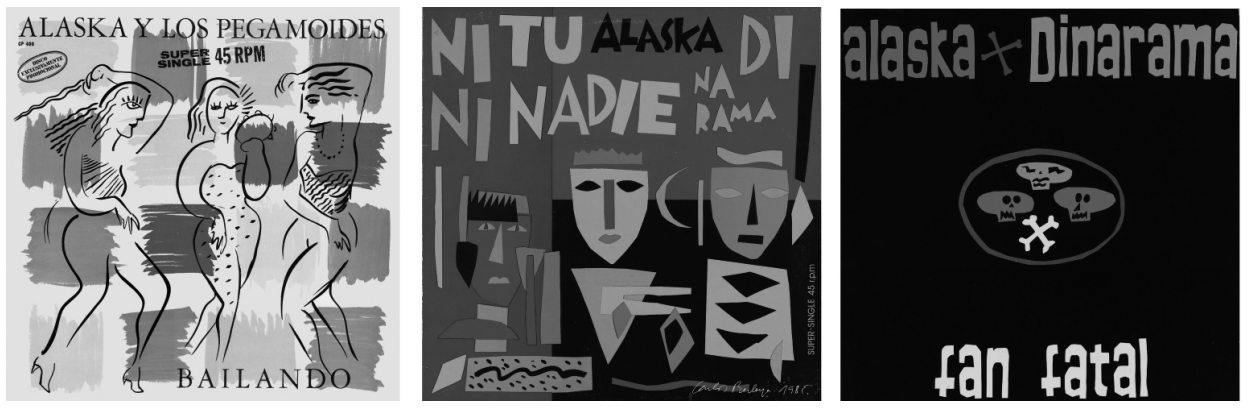

José María Cano: Después de vender millones de discos con su grupo Mecano y escribir una de las páginas más brillantes del pop español de los 80 , decidió un día terminar con ese mundo y seguir trasmitiendo sus sentimientos a través de la pintura. Aunque cogió los lápices antes que la guitarra, pues ya a los diez años comenzó a dibujar asistiendo a distintas academias donde pretendía formarse, de forma más académica, para la carrera de Arquitectura. Pero su juventud la ocupó en su grupo creado en Madrid a principios de los 80 y disuelto a finales de los 90. Tras un disco en solitario, la composición de una ópera y un traumático divorcio, José María Cano entra de lleno desde su residencia de Londres en el mundo del «Arte Contemporáneo», y lo hizo a lo grande, diríamos que a lo «Duchamp» con un «Ready made» bastante peculiar.

Su primera exposición, "This is just Business», trató sobre las cartas de divorcio mezcladas con dibujos de su hijo Daniel que padece el síndrome de Asperguer. Pintaba las cartas agresivas de los abogados de la parte contraria sobre fondos de paisajes desérticos o helados y las mezclaba con los dibujos de un niño de diez años, de tal manera que una carta agresiva, hecha con la intención de sacar el mayor número de dinero posible, además de dañar su imagen y causarle gran perjuicio moral, una vez pintada y colgada en la pared, adquiría valores completamente inesperados y convertía a la persona que había escrito esa carta en alguien vil y ruin, dándole una dimensión opuesta de lo que para él había sig-

16 Ibidem, pp. 108-109. 
nificado en un principio. Desde esta exposición y hasta la actualidad, ha tratado diversos temas en su obra como la violación de los derechos humanos, las guerras, la prostitución o el mundo de la banca. Partiendo de imágenes que son originalmente recortes de periódicos o fotos y utilizando la técnica de la encáustica da a sus personajes unos efectos densos y cremosos que le permiten moverse en el margen que hay entre lo real y lo verdadero.

Anthony Haden-Guest en su columna del Financial Times dijo «Cano recrea imágenes meticulosamente, aplicando hasta siete capas de cera en un proceso que puede llevarle hasta mil horas por obra».

Si Warhol utilizaba la información comercial para su obra, José María utiliza la información social, política y económica convirtiendo esos cuadros en monumentos, casi esculturas de efecto tridimensional. Ha manifestado con ironía que estos personajes son las nuevas Venus afroditas.
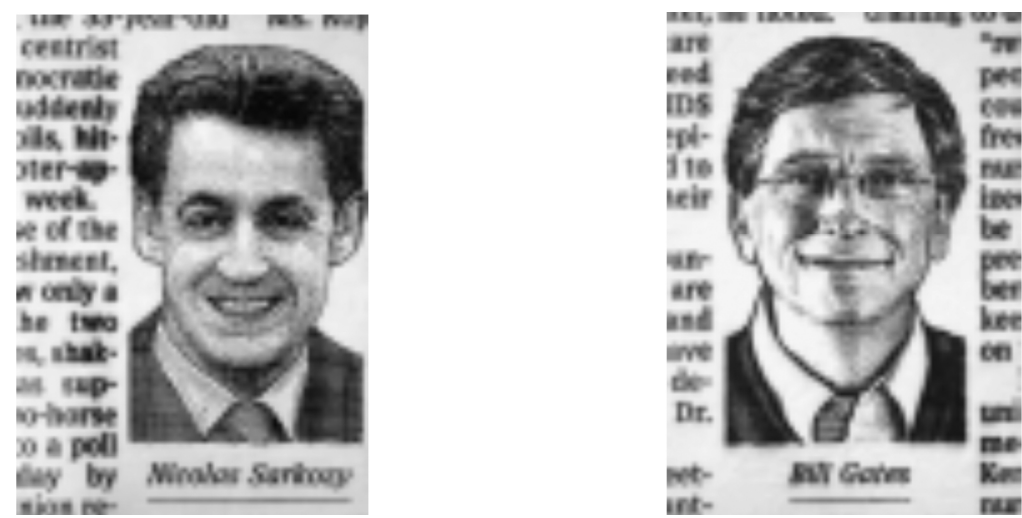

En los primeros días de septiembre de 2010 realicé una entrevista a José María Cano donde me habló del arte contemporáneo, de la relación entre música y dibujo y de su momento como artista plástico. Nada más saludarlo y explicarle en que consistía este trabajo, José María se lanza a dar su impresión sobre el arte contemporáneo:

«El arte ha ido como dicen los ingleses «run run society", no huyendo sino guiando, pero es relativo porque tampoco corre guiando... yo en realidad creo que el arte contemporáneo ha descubierto unos mecanismos tan sofisticados de auto protección que lo que hace es que la sociedad va más o menos por donde le da la gana y el arte reinterpreta su historia a gran velocidad y los artistas que tienen más que ver con lo que se ha hecho después, se destacan para que parezca que el arte ha influido en la sociedad».

Durante varios minutos, y de una forma muy inteligente y arrolladora, me sigue dando su impresión de los vaivenes del arte contemporáneo. Me habla de los 80 y las transvanguardias, también de la documenta donde Aquile Benito Oliva predijo que la pintura había vuelto para quedarse y se quedó, pero solo un rato. Pasado el tiempo 
aquellos artistas prácticamente han desaparecido. Cuando le comento que esta entrevista tiene que ver con músicos que también pintan me deja muy clara su postura:

«Hay músicos que pintan como hobby y yo realmente toda la vida me he dedicado al arte. No soy un músico que pinta. De ser algo o soy las dos cosas o soy un pintor que hizo canciones durante algún tiempo.

- ¿Cómo te introdujiste en el mundo del arte cuando eras un adolescente?

- Yo iba a principios de los 70 a guateques donde había discos y los ponía porque yo en mi casa no tenía. De pronto flipé con el «Imagine» de Jhon Lennon y de ahí me fui a los Beatles y me compré todos sus discos con 15 años, pero desde los 10 ya dibujaba tías en pelotas. No tenía ni idea de música, pero ya me gustaba dibujar y tenía una parte técnica.

- ¿Durante el tiempo que estuviste en Mecano pintaste?

-No! Durante ese tiempo sólo estaba dedicado al grupo, soy muy intenso con mi trabajo... por ejemplo: ahora mientras hablo contigo sigo dibujando... yo lo que hacía en aquella época era que el dinero que ganaba me lo gastaba en comprar arte, que fue una manera fantástica de estar en contacto y me dio un buen conocimiento y análisis de lo que ocurrió en el siglo XX y eso me ha dado elementos que ahora puedo manejar

-Tu con tus canciones has creado personajes, paisajes etc... ahora los creas con ceras, pinceles, espátulas...¿QQué diferencia hay?

-Mucha! En la canción hay dos elementos diferenciados: la música y la letra, que dan mucha información emotiva, cosa que no ocurre con el dibujo. Esto quiere decir que al oyente se lo das hecho. El que escucha "Me cuesta tanto olvidarte" siente exactamente lo mismo que uno que la escucha en Perú o en Madrid, ahora o hace 20 años. Lo único que cambia es el nombre de la chica de quien se acuerdan, pero la sensación es parecidísima. Frente a una obra de arte plástica lo que pone el observador es muchísimo más, para empezar, si es de arte contemporáneo, sin información no haces nada. Porque el arte contemporáneo es un club diferenciador, cuanto peor lo entienden los demás, más orgulloso está el arte contemporáneo de si mismo. Se requiere información para empezar, dependiendo del individuo es distinta, lo cual la percepción de aquello es completamente diferente. Hay gente que se pone delante de una obra de Damien Hirst y les parece una tomadura de pelo y otros dicen ¿me la puedo comprar?. En ese sentido la diferencia es brutal, casi te diría que opuesta. ella?:

-Usas una técnica ancestral, la encáustica. ¿por qué te has decantado por

-A mi me gusta mucho el porqué de las cosas, entonces la pintura empieza ahí, en el-Fayum. Porque pintar consiste en partir de una situación fluida para llegar a una situación sólida. Eso, a lo largo del tiempo ha ido descubriendo distintos sistemas y técnicas. Yo creo que aquellos retratos de muertos se hacían con mucha urgencia, y lo que importaba es que se secaran en el acto, porque sino imagínate el cuadro con el tío muerto allí delante, la familia llorando... eran absolutamente profesionales aquellos retratos de las momias. Así que creo usar una de las técnicas más antiguas.

- ¿Has momificado a Alan Greenspan no?

- Si y además se ha vendido hace poco por 65.000 libras. No quiero que nadie me reconozca nada, pero en el 2004 yo estaba centrado en este mundo de la economía, haciendo paisajes con las estadísticas... sin saber la que se nos venía encima. 
—Guillermo Pérez Villalta me dijo que se encontraba entre el final del Rococó y el principio del romanticismo. ¿Y tú?

—Pues yo fuera de España estoy considerado como un buen técnico y aquí... soy el que ha hecho el cartel de San Isidro 2010.

Como he comentado ya, Jose María Cano es una persona intensa que vive con pasión su trabajo, de ahí que no nos extrañe encontrar su obra entre las grandes casas de subastas internacionales como Sothesbys rodeado de los más grandes del arte contemporáneo.

Luis Eduardo Aute: Es otro de los músicos que ha dedicado su talento a la pintura, conocido también como cantautor y dueño de una extensa discografía que va desde el año 1968 al 2009, con más de 30 álbumes publicados de los cuales muchos de ellos tienen en la portada una obra del propio Aute. Comenzó como pintor antes que compositor; su obra plástica se inicia en 1961 y dura hasta la actualidad. Durante todo este tiempo ha confesado que su obra corresponde con sus estados de ánimo. Al principio utilizó más el color que poco a poco fue perdiendo, aunque con el tiempo ha vuelto a recuperarlo. Su universo es el ser humano y en el erotismo y las mujeres encuentra uno de sus puntos de inspiración. Su pintura recoge las influencias del surrealismo, dadaismo y las vanguardias, aunque él se considera un racionalista. También se ha expresado a través del cine, la poesía o la escultura. Algunas de sus canciones son himnos inter-generacionales como «Al alba», «Rosas en el mar» 0 «Aleluya.

Es sin duda el músico español que más carátulas tiene con sus propias pinturas. La siguiente puede que sea una de las mejores.

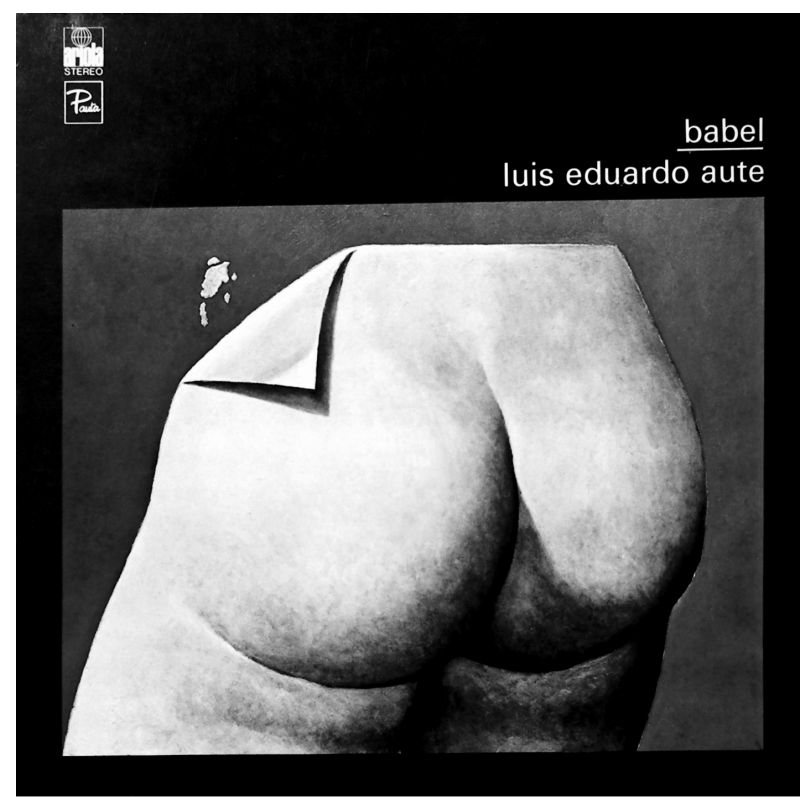


El disco «Babel» de 1975 tiene una de las carátulas que mejor se identifica con su obra pictórica, donde se articula cierto clasicismo con modernidad. Él quería publicar «Sarcófago» cosa que finalmente hizo, pero su compañía discográfica casi le puso como condición que publicara este otro. Es posible que la portada sea un regalo para los ejecutivos de aquel momento.

Manolo García: Ha fundado grupos como Los Rápidos o Los Burros, esenciales para conocer lo oleada punk catalana de finales de los 70 y principios de los 80 . Con «El último de la fila» su música llegó al gran público y sus canciones forman parte ya de la historia del poprock español. Desde que conocí a Manolo García, allá por los primeros 80 , siempre lo vi metido de lleno en todas las cuestiones gráficas o de diseño de imagen que tuviera que ver con su música. Fue más tarde, ya en los 90 , cuando Manolo empezó a enseñar esos dibujos y cuadros, muchos de ellos pintados en las habitaciones de los hoteles, entre concierto y concierto. Su pintura es de corte expresionista, de poderosas e inquietantes imágenes, colorista y onírica. Últimamente se puede ver su obra en Arco y galerías de arte. El mismo reconoce la conexión de sus creaciones: «mi manera de hacer canciones se complementa con los cuadros que pinto, siempre que compongo tengo un caballete de pintura al lado ${ }^{17}$.

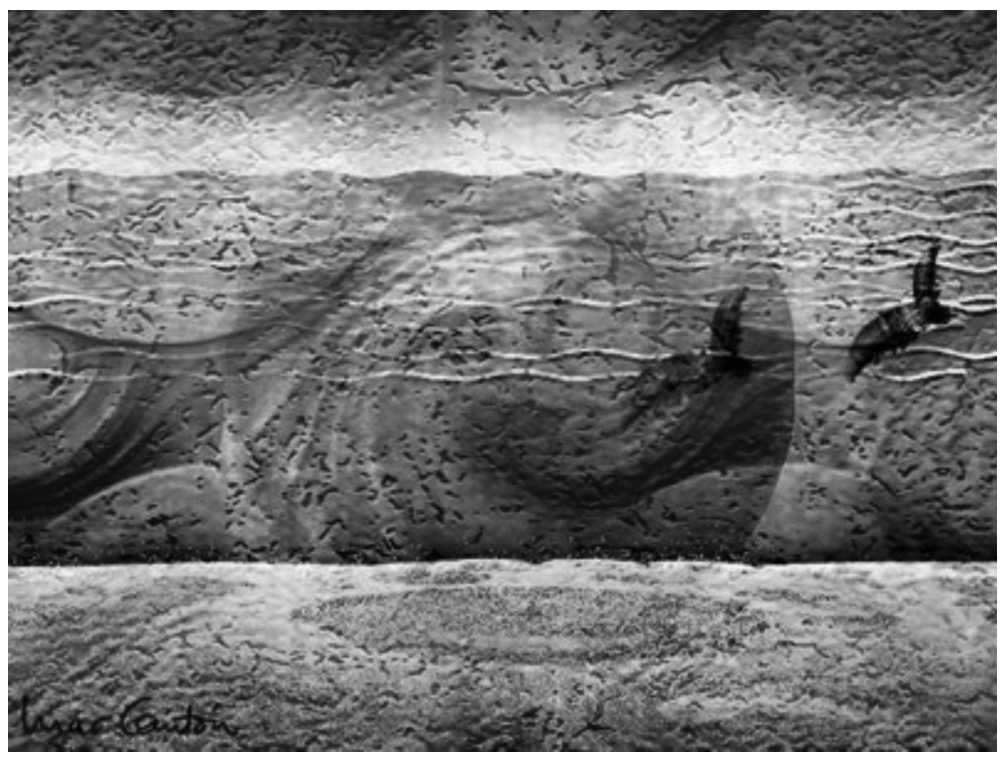

Camilo Sesto: Fue uno de los cantantes melódicos con una gran proyección, sobre todo en Hispanoamérica. Sus canciones son clásicos del pop en castellano y sus discos en ventas se cuentan por millones. Hace tiempo que se retiró en Miami donde desarrolló su faceta de pintor, se prodigó en galerías de la zona y sus telas se llegaron a vender a precios estratosféricos, me imagino que entre sus más acérrimos seguidores...

17 P. Sycet, ob. cit. 


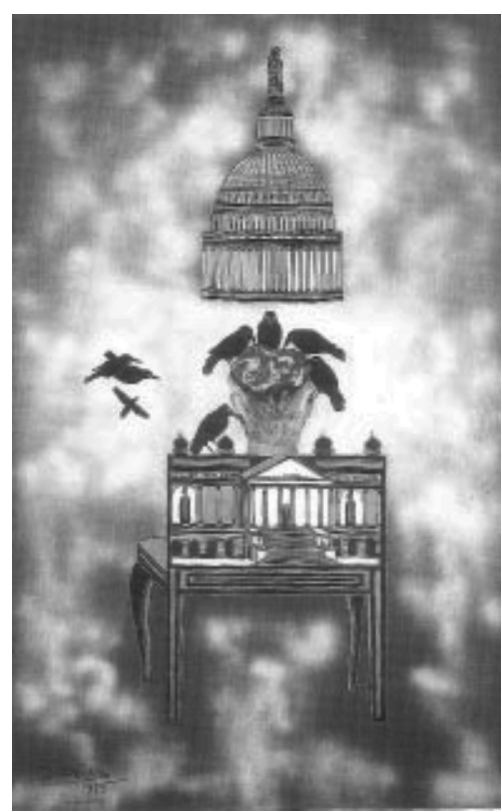

Alejandro Sanz: Fenómeno de masas adolescentes, últimamente ampliado al mercado latino. Siempre ha sido empujado por el potente marketing de las discográficas y tiene alguna canción que lo supera todo convirtiéndose en super popular como "Corazón partío». Como pintor debutó en una exposición individual en la galería Sen de Madrid en el 2002. Al referirnos a sus cuadros habría que hablar de un expresionismo colorista muy particular, a veces abstracto y otras de carácter figurativo.

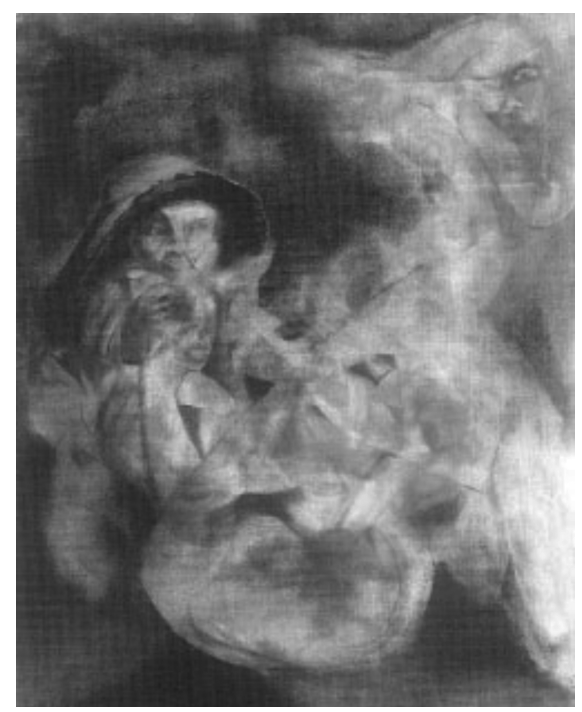




\section{PÁGINAS WEB}

http://www.fundacioncostus.com/costus/bio.htm

http://www.cancioneros.com/cc.php?NM=13\&TP=1

http://www.e-barcelona.org/index.php?name=News\&file=article\&sid=7637

http://www.fundacioncostus.com/costus/bio.htm

http://www.tomajazz.com/perfiles/avuijazz/avuijazz2007_disejazz.htm

http://www.caratulas.com/

http://lilicorrea.blogspot.com/2007/12/la-imagen-digital-el-mapa-no-es-el.html

http://www.sevillapress.com/noticia/6017.html

http://www.apoloybaco.com/caratuladisenoartespintura.htm

http://salvadorcardenal.com/pintor/es/

http://www.e-barcelona.org/index.php?name=News\&file=article\&sid=7634

http://www.diariovasco.com/pg060825/prensa/noticias/Cultura/200608/25/DVA-CUL-169.html

http://www.lossonidosdelplanetaazul.com/index.php?ltemid=55\&id=75\&option=com_content\&task=view

http://www.miquelbarcelo.info/obras_min_ok.php?Cat=55\&Tipo_obra=Portadas_de_disco\&Menu=sub2

http://www.adolfoceldran.com/discos/Silencio/Silencio.html

http://www.lavozdegalicia.es/hemeroteca/2007/05/12/5799447.shtml

http://www.taringa.net/posts/musica/1472854/Paco-Iba\%C3\%B1ez-(30-CDs).html

http://www.coveralia.com/noticias/Luis-Eduardo-Aute-publica-un-disco-doble-recopilatorioy-un-DVD-documental-483.php

http://enlafrontera.blogspot.com/

http://w3art.es/weblog_archivos/000395.php

http://e-valencia.org/index.php?name=News\&file=article \&sid=7336

\section{ENTREVISTAS PERSONALES:}

Enric Frigola. Coleccionista. Barcelona.

José Ramón Pardo. Coleccionista. Madrid.

Juan Pardo. Músico. Madrid

María del Mar Bonet. Músico. Barcelona.

Pablo Sycet,Alfonso Albacete y Carlos Franco. Pintores.

Guillermo de Osma y Daniel Cardani. Galeristas.

Guillermo Pérez Villalta.

Jose María Cano

Galería Joan Prats 
Cap12 14/11/2011 13:26 Página 290 